\title{
Climate change and the ecology and evolution of Arctic vertebrates
}

\author{
Olivier Gilg, ${ }^{1,2,3}$ Kit M. Kovacs, ${ }^{4}$ Jon Aars, ${ }^{4}$ Jérôme Fort, ${ }^{5}$ Gilles Gauthier, ${ }^{6}$ David Grémillet, ${ }^{7}$ \\ Rolf A. Ims, ${ }^{8}$ Hans Meltofte, ${ }^{5}$ Jérôme Moreau, ${ }^{1}$ Eric Post, ${ }^{9}$ Niels Martin Schmidt, ${ }^{5}$ \\ Glenn Yannic, ${ }^{3,6}$ and Loïc Bollache ${ }^{1}$ \\ ${ }^{1}$ Université de Bourgogne, Laboratoire Biogéosciences, UMR CNRS 5561, Equipe Ecologie Evolutive, Dijon, France. ${ }^{2}$ Division \\ of Population Biology, Department of Biological and Environmental Sciences, University of Helsinki, Finland. ${ }^{3}$ Groupe de \\ Recherche en Ecologie Arctique (GREA), Francheville, France. ${ }^{4}$ Norwegian Polar Institute, FRAM Centre, Troms $\varnothing$, Norway. \\ ${ }^{5}$ Department of Bioscience, Aarhus University, Roskilde, Denmark. ${ }^{6}$ Département de Biology and Centre d'Études Nordiques, \\ Université Laval, Québec, Québec, G1V OA6, Canada. ${ }^{7}$ FRAM Centre d’Ecologie Fonctionnelle et Evolutive, UMR CNRS \\ 5175, Montpellier, France. ${ }^{8}$ Department of Arctic and Marine Biology, University of Troms $\varnothing$, Troms $\varnothing$, Norway. ${ }^{9}$ Department of \\ Biology, Penn State University, University Park, Pennsylvania
}

Address for correspondence: Olivier Gilg, Laboratoire Biogéosciences, UMR CNRS 5561, Equipe Ecologie Evolutive, 6 Boulevard Gabriel, 21000 Dijon, France. olivier.gilg@gmail.com

Climate change is taking place more rapidly and severely in the Arctic than anywhere on the globe, exposing Arctic vertebrates to a host of impacts. Changes in the cryosphere dominate the physical changes that already affect these animals, but increasing air temperatures, changes in precipitation, and ocean acidification will also affect Arctic ecosystems in the future. Adaptation via natural selection is problematic in such a rapidly changing environment. Adjustment via phenotypic plasticity is therefore likely to dominate Arctic vertebrate responses in the short term, and many such adjustments have already been documented. Changes in phenology and range will occur for most species but will only partly mitigate climate change impacts, which are particularly difficult to forecast due to the many interactions within and between trophic levels. Even though Arctic species richness is increasing via immigration from the South, many Arctic vertebrates are expected to become increasingly threatened during this century.

Keywords: impacts; phenological changes; plasticity; range shifts; adaptations; threat; trophic interactions; mismatches; sea ice; tundra; parasites; geese; shorebirds; rodents; lemmings; large herbivores; seabirds; marine mammals; polar bear

\section{Introduction}

Several studies have already reviewed the ongoing and forecasted impacts of climate change on the ecology and evolution of vertebrates on Earth. ${ }^{1,2}$ Overall, changes in phenologies, in distributional range, in evolutionary adaptations-on the long term-and, in the structure and the dynamics of communities, are forecast to be the main biological consequences of climate change. However, due to regional differences in climate change and in biotic characteristics, climate-induced impacts on species will differ in their nature and magnitude between regions and ecosystems. ${ }^{3}$ Examples include the follow- ing: in Africa, water stress is expected to become the main constraint in the future, with arid and semiarid land projected to increase; in eastern South America, drought and increasing temperatures will induce a gradual replacement of tropical forests by savanna; in boreal regions, increasing rainfall and temperature will in many places allow the forest to expand in altitude and latitude, replacing the Arctic and Alpine tundras; and in many coastal lowlands, the elevation of sea level will replace terrestrial ecosystems by marine ones. In the Arctic, physical changes will be dominated by changes in the cryosphere (glaciers, permafrost, sea ice, and snow layers), primarily due to increasing temperatures. 
To understand how Arctic vertebrates will respond to these changes, we have to consider their particular history, the extreme physical environment they currently inhabit, and the relatively simple structure and composition of the communities to which they belong.

Of course, changes in climate are not entirely new, and Arctic vertebrates have already lived through several periods of "historical climate changes"although the speed and the extent of the current changes are probably unprecedented. However, unless we enter the realm of paleoecology, we know little about ecological responses of vertebrates to past changes in climate. Vibe's seminal study ${ }^{4}$ is one notable exception. He clearly showed, nearly 50 years ago, the importance of climate, and more precisely the availability of specific ice types, in determining the distribution of marine mammals on the west coast of Greenland. More recent analyses of decadal patterns of sea ice and their influences on marine mammals can also be used to predict that changes in recent years are likely to impact resident marine mammal populations at both regional and hemispheric scales. ${ }^{5}$

The Arctic biome is already changing, and this change is rapid and severe compared to other regions of the globe. It is expected that the changes that will take place in the Arctic in the coming decades will surpass what many Arctic vertebrates have experienced in the past, despite the extreme variability that is normal in the climate of the Arctic. Indeed, while the global mean surface temperature has warmed by $0.6-0.8^{\circ} \mathrm{C}$ during the 20th century, it has increased $c a$. twice as much in the Arctic during the same period. ${ }^{3}$ The consequences of this warming include decreases in snow, ice, and frozen ground layers, while precipitation has increased overall in the Northern hemisphere. ${ }^{3}$ The strong environmental constraints that prevail in the Arctic-including the harsh climate, strong seasonality, low productivity, and numerous ecological barriers-are likely to exacerbate the impacts that are expected due to direct influences of climate change. ${ }^{6}$

Documented declines in Arctic sea ice are symptomatic of these ongoing changes. Its overall extent, thickness, seasonal duration, and the proportion of multiyear ice have all declined. Multiyear sea ice has disappeared three times faster during the past decade than during the previous three decades, and seasonal ice is thus becoming the dominant sea ice type in the Arctic. If these trends continue as predicted by models, the Arctic Ocean should become ice free in summer well before the end of this century, ${ }^{7}$ and this would be a first for Arctic marine systems during the last $5+$ million years. ${ }^{8}$

Arctic vertebrates possess many adaptations that have enabled their persistence in Arctic environments. These traits include behavioral (e.g., day torpor, seasonal migration), physiological (e.g., seasonal metabolic adjustments, fasting ability), and morphological (e.g., white coats, short extremities, extensive blubber layers, thick fur, lack of dorsal fins among ice whales) mechanisms. But despite their extreme and varied adaptations to coping with the harsh and highly variable Arctic climate, these species are considered to be particularly vulnerable to ongoing climate changes. Their peculiar lifehistory strategies have served them well in a lowcompetition situation but leave them vulnerable to competitive stress from temperate species that are already invading their ranges. Arctic endemics have little potential for northward retraction to avoid such overlap. In addition, they may have limited capacity to deal with exposure to disease because of their limited exposure in the past. Furthermore, the heavy lipid-based dietary dependence of some Arctic species leaves them disproportionately vulnerable to the effects of lipophilic contaminants.

Arctic vertebrates can adjust to cope with climaterelated changes (i.e., through their phenotypic plasticity) or adapt (via the differential selection of some genotypes) in many different ways. The aim of our paper is to review these different responses and, whenever possible, to present examples of the impacts of climate change at the community level, explicitly taking into account interspecific interactions. Given the wide range of possible interactions, predictions made at this level usually remain speculative. On the other hand, predictions that overlook interaction processes would lack realism. To avoid these pitfalls, the examples supporting our text are primarily chosen from the few biological models that have already been studied comprehensively in the Arctic in recent years-that is, rodents and their predators, geese and shorebirds, large herbivores, seabirds, and marine mammals and their prey.

Our paper is structured in nine sections and follows a process orientation, rather than the traditional species by species approach. In the first section, we present a general outline of how 
vertebrates will respond to changes in the cryosphere, because most species living in the Arctic biome are exceedingly dependent on snow and ice regimes for their reproduction and survival. Second, we give a brief overview of some important ecophysiological constraints that directly link climate and species and can hence result in very rapid responses. In the third and fourth sections, we provide an extensive review of the main responses of Arctic vertebrates to climate change: changes in phenology, that is, the timing of seasonal activities (e.g., migration, calving, egg-laying), and range shifts, that is, moving to track suitable habitat. ${ }^{1,2,9,10}$ The fifth section aims to present the need for considering interactions, especially in relatively simple communities such as those found in the Arctic, in order to understand the complexity and diversity of the observed responses. A particular case study involving parasites is presented in section six as an example. The seventh section provides an evolutionary perspective for the phenotypic and genotypic responses that are likely to arise in Arctic vertebrates, highlighting how molecular ecology can help us to infer the fate of these species. In the eighth section, we list some principle knowledge gaps that currently prevent us from having a better understanding or being able to forecast climate change responses well. Finally, we summarize the general trends that emerged from our review in a concluding section.

\section{Coping with a changing cryosphere}

Ongoing changes in snow and sea ice conditions will have strong and wide impacts on Arctic vertebrates' habitats and food resources. These widespread and long-lasting layers of frozen water are far from homogenous. Dozens of different types of snow and ice can be distinguished according to their thickness, age, density, temperature, chemical composition, physical structure, location (e.g., latitude, which accounts for temporal differences in solar radiation), history, etc. Depending on the quality and quantity of snow or ice found in their habitats, Arctic vertebrates will react differently in order to optimize their fitness. Forecasted changes in the Arctic cryosphere will hence impact Arctic vertebrates in many different ways that will be presented in more details in the following sections, but let us just start here with a few examples chosen from among some of the most important vertebrate guilds found in the Arctic.
The winter is a key period in the annual cycle of Arctic small mammals as some-for example, the Arctic lemmings - live under the snow for up to nine months of the year at the most northerly sites; they even reproduce under the snow. The increase phase of lemming population cycles is almost always driven by reproduction under the snow, ${ }^{11}$ and thus events occurring under the snow have a strong impact on their population dynamics. Lemmings clearly choose particular sites under the snow for their winter activities. The distribution of their winter nests show a strong association with deeper snow, and the greatest probability of occurrence is at snow depths from 60 to $120 \mathrm{~cm} \cdot{ }^{12,13}$ A deep, dry snow cover reduces thermal stress on small mammals that overwinter in subnivean spaces, most notably by dampening the daily temperature fluctuations that they experience. ${ }^{12,14}$ Many parts of the Arctic receive less than $40 \mathrm{~cm}$ of snowfall during a winter, but this is often redistributed heavily by wind, creating a mosaic of habitat patches differing substantially in snow depth, with snow being trapped by topography and vegetation. A recent manipulation experiment that altered snow cover showed that increasing the snow depth in marginal winter habitat increased habitat use by small mammals in these areas, as expected, but the impact on demography (reproductive rate or mortality due to predation) was less clear. ${ }^{14}$ Nonetheless, it is likely that change in snow depth or snow quality (e.g., increased amount of wet snow, icing, or collapses in the subnivean spaces, which increase the energetic costs incurred in getting access to food plants or in severe instances totally obstruct access) caused by climate warming will have a strong impact on small mammal population dynamics. Such findings have been reported recently from some parts of Fennoscandia and Greenland (see section "Cascading changes"). ${ }^{15,16}$

Among large mammals, variation and trends in snow cover, especially during late winter, will likely also affect foraging ecology and population dynamics. Evidence from long-term monitoring at Zackenberg in northeast Greenland indicates, for example, that biomass production and spatial synchrony in the growth of the main willow forage species for muskoxen Ovibos moschatus there, Salix arctica, are both negatively related to snow cover. ${ }^{17}$ Increasing snowfall in the High Arctic with continued warming could therefore translate into increased spatial 
heterogeneity of willow growth, which might result in increases in local density-dependent competition for forage among muskoxen. ${ }^{17}$ In the High Arctic Archipelago of Svalbard, population dynamics of Svalbard reindeer Rangifer tarandus platyrhynchus display a generally positive association with an index of winter ablation, or the energy available for snowmelt, suggesting that continued warming may promote an increase in that population through reduced winter starvation mortality. ${ }^{18}$

Most tundra breeding birds (shorebirds and passerines alike) are long-distance migrants, and many of them winter in rich intertidal flats in temperate and tropical regions. By spending only some weeks in the Arctic, they avoid the harsh Arctic winter but still take advantage of the summer boom of food on the tundra, particularly to raise their young. ${ }^{19}$ Indeed, many tundra birds rely heavily on invertebrate food during the entire breeding season. For the adults, invertebrate food is particularly important for the development of eggs and for building up body stores to be used during the incubation period, while hatchlings either feed themselves (shorebirds) or are fed (passerines) with invertebrates during their growing period. ${ }^{20,21}$ Both adult and juvenile shorebirds have to build up body stores rapidly during the postbreeding period, based on invertebrate food, for their long autumn migration, while passerines feed primarily on seeds that ripen at this time of the year. The first weeks following the shorebirds' arrival on the tundra (i.e., when eggs are formed) are particularly critical, because snow melt and weather conditions in general vary a lot from year to year in most parts of the Arctic. ${ }^{21}$ Because global warming is expected to result in earlier snow melt and more benign summer weather, tundra birds may well benefit from more favorable breeding conditions in most years. ${ }^{21}$ However, they might also suffer from more variable conditions, because the amount of snow falling in winter is expected to increase in most Arctic regions, a change that, in combination with cooler springs, could result in more chaotic-both in regularity and severity-breeding conditions (also see the following section).

When moving to ice loss-related threats to Arctic marine vertebrates, the polar bear Ursus maritimus is undoubtedly the first species people have in mind. During their short evolutionary historythey diverged from brown bears Ursus arctos less than 200,000 years ago ${ }^{22}$ - polar bears have become highly adapted to life on the sea ice. Their dependency on sea ice is mainly via their extreme specialization in feeding on ice-associated seals, particularly ringed seals Pusa hispida and bearded seals Erignathus barbatus. ${ }^{23}$ In addition, sea ice is important because it is a solid substrate on which bears can move and rest. Coastal sea ice habitats are particularly important to females with dependent young. ${ }^{24}$ Some bears use sea ice in all seasons, while other bears stay on land for much of the year, but most feed at least seasonally on ice-associated seals. However, it is noteworthy that ice linkage varies geographically for bears among the different populations and also among individuals; different spaceuse strategies can be found even within polar bear subpopulations. ${ }^{25}$ The observed loss of sea ice in recent decades has raised concerns about the future of polar bears in the Arctic. ${ }^{26-28}$ In areas where sea ice is absent in summer, polar bears depend on fat reserves acquired in the peak feeding period to get them through long periods of fasting. Polar bears are unique among larger mammals in their ability to survive many months without feeding. Reproducing females may fast for up to eight months and still nurse cubs. There is, however, a balance between fat reserves and survival/breeding capabilities. In some areas where sea ice breaks up earlier in spring and access to ringed seal pups has been reduced, for example, in western Hudson Bay, survival of cubs, subadults, and even older bears is lower in years with early ice breakup, and recent longer icefree summers are concomitant with a reduction in this subpopulation's size. ${ }^{29}$ In the southern Beaufort Sea, survival of adult females was considerably higher in 2001-2003, when the mean ice-free period was 101 days, compared to 2004-2005, when it was 135 days. Breeding rates and cub survival also decreased during the latter period. ${ }^{30}$ Another change in the Alaskan part of the southern Beaufort Sea is a profound decline in the proportion of females denning in the multiyear sea ice: $62 \%$ in $1985-1994$ versus $37 \%$ in $1998-2004 .^{31}$ However, in most areas of the polar bear's range, denning occurs only on land. In Svalbard, many female bears denned on the isolated island Hopen decades ago. But in recent years, when sea ice has not extended south to Hopen in the late autumn, almost no denning has been documented on this island. ${ }^{26}$ Reduction of sea ice has also been proposed as a causal factor 
behind increased intraspecific predation, ${ }^{32}$ drowning of bears during storms, ${ }^{33}$ and extraordinary long swims that may lead to loss of cubs. ${ }^{34}$ In areas where polar bears have high levels of lipophilic pollutants, toxins and their metabolites are released into the blood stream under periods of nutritional stress. This is a concern given the longer fasting periods being experienced by populations with reduced ice conditions, although the exact effects this may have on survival and reproduction are not known. ${ }^{35}$

Other marine mammals will also face important environmental changes in the Arctic that will alter the communities in which they live, ${ }^{36-38}$ particularly pagophilic ("ice-loving") species. ${ }^{5,6,39-45} \mathrm{~A}$ summertime ice-free Arctic Ocean will have major implications for ocean circulation and our global climate system $^{3,46,47}$ and will also have impacts throughout marine food webs. Implications for the organisms that are residents of the unique Arctic sea ice habitat have been described as "transformative." ${ }^{48}$ For its mammalian residents, Arctic sea ice has been a spatially extensive, virtually disease-free habitat that is to a large extent sheltered from openwater predators (i.e., killer whales Orcinus orca) and human impacts (e.g., oil development, shipping). It has been a low-competition environment that has provided a spatially predictable, seasonally rich food supply, particularly in the marginal ice-edge zone and at predictable polynyas. ${ }^{49,50}$ It is furthermore sheltered from storm action for the mammals that have succeeded in dealing with the prevailing cold temperatures, risk of ice entrapment, dramatic seasonality, and other aspects of an iceassociated lifestyle. ${ }^{41}$ Seven seal species and three whale species have evolved within the Arctic sea ice environment, or joined it, over the millions of years of its existence. ${ }^{51}$ Loss of sea ice represents a reduction in available habitat for pagophilic mammals, and this is already affecting the distribution, body condition, survival rates, and reproductive output of some species. ${ }^{41}$ In the longer term, it is expected that foraging success, fertility rates, mortality rates, and other population parameters will be impacted for additional populations and species. Northward range contractions are possible only within a limited scale before deep Arctic Ocean conditions replace the productive shelf habitats upon which most Arctic marine mammals depend. Generally speaking, specialist feeders are likely to be more heavily impacted by changes in Arctic food webs that will accompany sea ice losses compared to generalist feeders. In addition, widely distributed species will have greater chances of shifting to suitable regions than species with restricted ranges. Ice breeders that require long periods of stable ice late in the spring season are also likely to be impacted more rapidly than late winter ice breeders that require ice for shorter periods of time. ${ }^{42,43,52}$ Other risks posed by climate change include the increased risk of disease in a warmer climate, the potential for increased effects of pollution, increased competition from temperate marine mammal species that are expanding northward, and stronger impacts of shipping and development in the north-in particular from the petroleum industry-in previously inaccessible areas. ${ }^{41}$ In combination, these various changes are likely to result in substantial distributional shifts and abundance reductions for many endemic Arctic marine mammal species.

Although Arctic seabirds are highly adapted to extreme environmental conditions, their energy balance is nonetheless affected by harsh environments. Heat losses in cold air, water, or in stormy conditions can be extremely high despite the waterproof and well insulated plumage of adults. ${ }^{53}$ Some species such as guillemots and little auks Alle alle can be found dead by the thousands in coastal areas following severe winter storms. ${ }^{54}$ Because the intensity and frequency of winter storms are forecast to increase with climate warming, ${ }^{6,55}$ important impacts are expected on seabird energetics and winter survival. The relative sensitivity of seabirds to climate changes is also obvious during the breeding season for their chicks, whose downy plumage is much less waterproof and a poorer insulator than that of the adults. Chicks are highly vulnerable to changes in wind speed and precipitation. Indeed, harsher wind conditions as well as more frequent heavy or freezing rain will most likely impact their energetics and result in higher mortality. Even for the extremely well-adapted High Arctic ivory gull Pagophila eburnea, a single day of rain accompanied by strong winds can destroy all clutches and broods in some colonies in some years (Gilg and Aebischer, personal communication 2011).

\section{Ecophysiological constraints}

The most direct link between climate and the ecology of most species is probably the physiological interplay between environmental and body 
temperatures. Each organism lives within a given range of temperature (i.e., "thermal window"). ${ }^{56}$ To minimize maintenance costs, thermal windows are thought to evolve to be as narrow as is possible around normal environmental temperature(s), which results in different temperature tolerance ranges between species, subspecies, or even populations of a given species living in different regions. When environmental temperatures shift closer to one edge of the individual's thermal window-for example, climate warming driving the temperature higher - the individual's physiological performance (e.g., growth, reproduction, foraging, immune competence, competitiveness) will be negatively impacted. ${ }^{56}$ This is contrary to the layman's belief that an increase in environmental temperature will improve the "welfare" of Arctic vertebrates. Climate change is forecasted to have a stronger negative impact on species that have narrow thermal windows, long generation times, and limited genetic diversity. ${ }^{56}$ Conversely and at a larger geographic scale, some vertebrate species currently living at the southern border of the Arctic region will benefit from climate warming and will be able to expand northward, because their thermal windows will soon match the new environmental temperatures found in the Arctic (see also section "Advanced phenologies"). Because aquatic habitats have more stable temperatures than terrestrial ones, most aquatic invertebrates and fish have narrower thermal windows than warm-blooded vertebrates and are probably more sensitive to changes in environmental temperatures (see examples for sockeye, Pacific salmon, Atlantic cod, and zooplankton). ${ }^{57-59}$

Because the energy budget of an individual integrates both biotic and abiotic constraints, a bioenergetic approach can be used to assess the impacts of climate change. For instance, seabirds wintering in the North Atlantic experience an energetic bottleneck in November and December due to low temperatures and strong winds. ${ }^{53} \mathrm{~A}$ milder climate in this region would hence likely increase their winter survival and allow other less cold-adapted species to use these areas in winter. One of the main inferences from bioenergetic studies to date is that the impacts of climate change in the Arctic are likely to stem from the immigration of new colonizing species as much if not more than from the disappearance of current Arctic species. And some particular species, like hibernating mammals, should benefit - increase in abundance and distributionmore from climate change than others. ${ }^{60}$

Changes in hormonal responses are also expected in Arctic vertebrates as a result of climate change, with potentially very important outcomes on individual fitness. The stress axis in particular is believed to play a central role in the adaptation of birds and mammals to a changing environment. For many of them, breeding is only possible below a given stress response. An increasingly stressful environment, whether due to direct abiotic changes (e.g., temperature, snow, or ice cover) or to indirect biotic changes (e.g., new competitors, changing predation pressure), could negatively impact the fitness of Arctic vertebrates. ${ }^{61}$ Expected range shifts will help some Arctic vertebrates maintain their stress levels within acceptable ranges, but changes in food resources and availability, which also impact the stress axis, also need to be taken into account to predict their overall responses. Finally, hormonal responses and immune status are also modulated to some extent by pollutants. ${ }^{61,62}$ The future impact of contaminants will likely be correlated to the intensity of climate change; ${ }^{63}$ pollutants make it even more difficult to untangle causes and consequences of climate-induced impacts on the ecophysiology of Arctic vertebrates.

\section{Advanced phenologies and trophic match/mismatch}

Because ongoing climate changes are relatively rapid while most Arctic vertebrates are long-lived animals with slow population growth rates and long generation times, selection for the most adapted genotypes to new environmental conditions will likely be too slow to guarantee the survival of these species in the short term (see section "Evolutionary responses"). Instead, phenotypic plasticity is likely to be the principle response mechanism that will permit Arctic vertebrates to respond to the rapid, ongoing changes. ${ }^{64}$ If individuals can adjust rapidly to new environmental conditions by changing the timing of their migration or the initiation of their annual breeding events, then, in some cases at least, their populations could be little impacted by the climateinduced changes described earlier. Advanced phenologies are a widespread response of plants and animals to changes in climate. They have already been described in recent decades for organisms living in a wide variety of areas around the world, 
including the Arctic where they have been most pronounced (up to 20 day shifts during the past decade for some plants and invertebrates). 2,6,65,66 Unfortunately, phenologies are not plastic for all traits, nor among all species. For some vertebrates, the timing of migration or breeding is regulated by a rigid endogenous clock or by fixed environmental clues (e.g., photoperiod) and cannot therefore be adjusted to other environmental conditions that may be changing. ${ }^{67}$ For such species, shifting their distribution range in order to track their optimal environmental conditions-abiotic but also biotic if interacting species also shift their range-might be a more relevant response. If they are not able to adjust the timing of their life cycle events (e.g., migration, breeding, molting, fattening) to temporal changes in the quality of their habitat and especially to their food resources, then they will face mismatches and will be left with no other choice than moving to different habitats, using different food resources (both responses allowing them to "rematch"), or their populations will decline. ${ }^{68}$

Mismatches have both trophic and dynamic implications. If temporal relationships are disrupted or altered, fitness will be affected, ${ }^{69}$ leading to declines in population abundance. ${ }^{70}$ Different trophic levels_plants, herbivores, predators-may respond differently to warming, which may lead to mismatches in the timing of events between trophic levels. For instance, gosling growth in herbivorous geese is dependent upon good synchrony between hatching and the seasonal change in plant nutritive quality, especially protein, an essential nutrient for growth. ${ }^{71}$ In snow geese Anser caerulescens breeding in the High Arctic, there is evidence that in years with early and warm spring, gosling growth is reduced, ${ }^{72}$ probably because they hatch too late to benefit from high-quality plants. This has a negative impact on the recruitment of young because their survival during the autumn migration is dependent on their mass at the end of the summer. Climate warming will increase this mismatch and may result in a reduction of recruitment in some populations.

Large terrestrial herbivores may also be susceptible to trophic mismatch derived from an advance in spring phenology associated with warming. In West Greenland, for instance, long time series of observational data indicate that April warming is associated with an advance in the emergence date and rate of emergence of species of plants that comprise im- portant forage for caribou. In this case, despite an advance in the onset of spring plant growth, the timing of calving by caribou has not advanced to the same extent, with the result that calving is not well synchronized with the onset of the plant growing season in the warmest years, when calf production is lowest. ${ }^{69}$ There is also a spatial component to trophic mismatch, in this case because during warm springs, the timing of plant growth is more highly synchronized across the landscape on the caribou calving grounds, reducing the advantage that spatial heterogeneity in plant phenology otherwise affords highly mobile herbivores such as caribou. ${ }^{73}$ These observations suggest that warming may, in populations of caribou inhabiting regions with typically short plant growing seasons, adversely affect offspring production and survival if the timing of calving is inflexible and, thereby, unable to keep pace with advances in the timing of spring plant growth on calving grounds. Indeed, recent work indicates that caribou lack an internal circadian clock due to selection for a circ-annual clock and thus may display a physiologically "hard-wired" timing of parturition. ${ }^{74}$

In the Arctic, most mismatches are likely going to be related to the advancement of the spring. ${ }^{66}$ Among Arctic shorebirds for example, initiation in egg laying is governed by a combination of spring cues, including snow cover and food availability during the egg-laying period, and it occurs in early June in most areas. If the snow melts early, invertebrate emergence could be affected. This is the strongest factor governing chick success, and shorebirds can adjust their laying date to these local conditions by up to four weeks. ${ }^{75}$ In years with late snow melt, the birds have to wait for the snow to disappear, which might result in a mismatch between invertebrate availability and chick growth later in the season. However, in some regions, climate change could actually improve the match between the annual cycle of shorebirds and the phenology of their prey. There are indications that Arctic shorebirds may suffer from trophic mismatch on the High Arctic Siberian breeding grounds, ${ }^{76}$ while they might benefit from a better temporal fit between their reproductive cycle and the availability of their food in other places-for example, in High Arctic Greenland. ${ }^{21,77}$ The reason for this difference is that the duration of the peak in invertebrates on the High Arctic Siberian tundra is rather short, while invertebrates are plentiful for 
a more extended period in High Arctic Greenland. Hence, shorebird chicks in High Arctic Greenland may benefit from earlier appearance of sufficient amounts of invertebrates, while some of their later arriving Siberian counterparts-due to often later snow melt than in Greenland-may not be able to hatch in time for the peak.

\section{Marine environments}

Phenological adjustments also occur in marine ecosystems. The reduction of sea ice extent in the Arctic will allow earlier access to benthic feeding grounds and create new areas of open water earlier in the season for foraging, which could lead to changes in seabird breeding times. Falk and Møller ${ }^{78}$ showed that the phenology of northern fulmars Fulmarus glacialis breeding in northeast Greenland was correlated to the sea ice dynamics of a nearby polynya. Similarly, Canadian northern fulmars as well as thick-billed murre Uria lomvia in West Greenland have been shown to respond to sea ice conditions by adjusting their timing of arrival at their colony, arriving later when the sea ice was more extensive. ${ }^{79,80}$ A decrease of seasonal ice distribution should be beneficial to many Arctic seabird populations, as this may advance the start of their breeding season and therefore allow more time to raise their chicks, provided these species are not indirectly affected by other mismatches - for example, between plankton bloom or fish prey availability and the chick rearing period. ${ }^{81}$ But sea ice declines will also be detrimental to some of the most typical High Arctic species, such as the ivory gull and several species of marine mammals (described later), that are sea ice specialists. ${ }^{41,82}$ These contrasting effects are sometimes even found between populations of the same species. Thick-billed murres breeding in the Canadian Arctic experience a beneficial effect of a reduced sea ice season at the northern limit of the breeding range due a lengthening of the breeding season but a detrimental effect at its southern limit, because it leads to mismatches between the timing of fish prey availability around the colony and the chick rearing period. $^{83}$

Along western Hudson Bay there has been a climate-driven increase in the overlap between nesting geese and polar bears. ${ }^{84}$ Late ice formation in fall and early break-up has extended the terrestrial period for the bears. This means that the bears now forage on energy-rich goose eggs for a longer pe- riod, which can result in widespread failure of goose nests in the earliest ice breakup years. In this case, the increased match between bears and geese is beneficial to the predator but highly detrimental to the prey. In Svalbard, increased presence of polar bears at barnacle goose Branta bernicla colonies in recent years has contributed to a decline in goose numbers in some coastal areas. ${ }^{85}$

Beyond sea ice extent, the increase in sea surface temperatures also affects the breeding phenology of seabirds.$^{86}$ Despite the possibility for certain seabird species to adjust their breeding time in response to a change in their physical environment, most of them might face climate change-related modifications of the spatial and temporal distribution of their preythat is, trophic mismatch between predators and resources. ${ }^{68}$ For instance, an earlier melting of seasonal sea ice in the Arctic will advance the timing and modify the rate of nutrient supply in upper surface layers, therefore affecting the timing and species composition of the phytoplankton spring bloom. This change will in turn affect the zooplankton and fish communities ${ }^{81}$ and modify their availability for predatory seabirds during their respective breeding seasons. To cope with these changes, seabirds have to breed earlier to follow the timing of prey availability. However, while this seems to be possible for some species-described earlier-it might not be the case for all of them. For example, seabird species nesting in crevices or burrows-little auks, auklets, puffins, etc.-can only access their nest when snow has melted and might therefore be limited in their response, as future climate changes are also expected to be associated with an increase in precipitation including snow fall.

Many ice-associated marine mammals use traditional breeding sites where these broadly dispersed populations congregate at very specific times-for example, harp seals Phoca groenlandica. These rendezvous match availability of their ice habitat, but also match food availability at the time of weaning of the young. As the sea ice season contracts, it is easy to envisage mismatches occurring between the timing of independence of the young and the lower trophic prey upon which they depend. Many temperate whale species migrate into the Arctic to feed in the marginal ice-edge zone, taking advantage of the spatially and temporally predictable late spring and early summer high productivity. In the future, it is likely that the Arctic marine ecosystem will be 
more productive in an overall sense, but it is also likely that prey will be more dispersed and hence more energetically costly to acquire.

As illustrated by the few examples described earlier, it will often be difficult or even sometimes totally impossible for Arctic vertebrates to adjust their phenologies in order to avoid mismatches. Responses to such challenges will be particularly difficult for species that use different habitats or food resources during their annual life cycles-for example, migratory species wintering outside the Arctic or species like salmonids using both oceanic and continental ecosystems; see also the section on "Cascading changes." 87 Indeed, the various mismatches these species will face in these different habitats throughout the year will be different in speed, intensity, and nature, and must therefore be solved by differentand sometimes antinomic - responses.

\section{Poleward changes in habitat and species distributions: a large-scale paradox of enrichment}

Due to various underlying processes already presented in other sections of this review (e.g., physiological constraints, specialization for some habitats and prey, limited phenological plasticity, interspecific interactions, biogeographical history, etc.), every species uses a given geographical area (delimited by its distribution range) characterized by a specific climate (sometime used to define species' "climatic envelopes"). ${ }^{88}$ As seen in the previous section, many species try to adjust to their changing environment (e.g., by changing the timing of their annual cycle) in order to stay in their current distribution range, but the phenotypic plasticity of individuals is finite and such adjustments are therefore limited. ${ }^{89}$ Hence, shifting the latitude or altitude in which they live in order to track their optimal environment appears to be a better strategy in the long term, especially for Arctic vertebrates that are extremely well adapted to their harsh environment but that have limited evolutionary capabilities on short time scales (see section "Evolutionary responses").

Poleward shifts have been documented for many species in recent decades, even for animals that live only within the Arctic region. ${ }^{90-93}$ As for phenological changes, given the intensity of climate change in the Arctic, range shifts are expected to be more pronounced here than in other biomes. In a strict sense, range shifts describe situations when both the southern (or lowest) and northern (or highest) borders of distribution ranges are constrained by climate and can hence move as a consequence of climate change. There are situations, however, when only one of these borders is constrained by climate- the other being constrained by geographical barriers, competitors, etc. In these cases, climate warming can either induce a decrease in distribution range-if the southern border is constrained by climate-or an increase. Several predictive models based on habitat utilization by feeding or nesting geese follow this rationale. ${ }^{94,95}$ Jensen et al. ${ }^{96}$ recently attempted to predict the future distribution of pink-footed geese Anser brachyrhynchus in Svalbard, considering that warm temperatures will create a longer summer season, thereby increasing the probability that geese will be able to complete their breeding cycle, and also experience increased food availability. According to their model, a $2^{\circ} \mathrm{C}$ increase in summer temperature should lead to an expansion in goose distribution and ultimately an enhanced population growth (but also see contrasting results based on seasonal changes in food quality in the previous section).

Another peculiarity of range shifts in the Arctic is related to the geophysics of the Earth. Any poleward shift in species distributions will mechanistically lead to a decline in the size of these ranges-a "polar squeeze" - the surface of latitudinal belts decreasing northward (e.g., a $1^{\circ}$ Lat. by $1^{\circ}$ Long. area covers $c a .6200 \mathrm{~km}^{2}$ at $60^{\circ}$ Lat. but only $4200 \mathrm{~km}^{2}$ at $70^{\circ}$ Lat. and $2100 \mathrm{~km}^{2}$ at $80^{\circ}$ Lat.). The most severe losses should therefore concern habitats that already reach the highest possible $\left(90^{\circ}\right.$ Lat.) or potential (see later) latitudes, because surface lost in the South of their range cannot be fully compensated by the colonization of new areas in the North.

Sea ice is probably the best example of a habitat that can only decline under current climate change scenarios, because it already occupies the northernmost seas on Earth. Poleward shifts will be impossible for species already distributed in these extreme regions. In addition, retractions of sea ice that occur to the degree that the remaining ice is no longer over productive shelf seas, but instead over the deep, unproductive Arctic Ocean, are likely to have extreme impacts and may induce tipping points. The well-documented polar bear case has already been presented, but this will also be the case for less well-known species such as the ivory gull and the 
ice-dependent seals that require sea ice on a yearround basis. ${ }^{41,82,97}$ In the long term, the disappearance of summer sea ice in most of the Polar Basin may restrict ice-dependent species to the north coasts of Greenland and Ellesmere Island (Canada), where multiyear ice is predicted to last longest or even drive some of these species to total extinction.

Some terrestrial habitats like the High Arctic polar deserts are similarly threatened because there is virtually no new area to colonize for the inhabitants of these areas, including the vertebrate species they host - for example, the Peary caribou Rangifer tarandus Pearyi. This "dead end" problem can be a concern even in low-Arctic regions. Here, narrow belts of open tundra are currently colonized at their southern borders by shrub communities, while the typical open tundra is prevented from extending northward due to bordering seas (e.g., in northern Alaska and on the continental part of northern Russia).

Species and subspecies that already have small distribution ranges, small population sizes, or that are to some extent dependant on typical Arctic habitats like sea ice (e.g., polar bear, walrus Odobenus rosmarus, narwhal Monodon monoceros, bowhead whale Balaena mysticetus, ivory gull, and a few others) or High Arctic tundra (e.g., several wildfowl and shorebird species, muskox, several reindeer subpopulations, etc.) will hence face a growing risk of extinction during the coming decades. ${ }^{21,98,99}$

Despite this dark picture for endemic Arctic species, many "meridional" species are colonizing the Arctic and their marginal Arctic populations are increasing. Due to their ability to cross-oceanic barriers, many of these species are fish, seabirds, seals, and cetaceans, with the highly visible colonial seabird being the best documented group. Climate change is expected to induce northward shifts in the distribution of most seabirds and some marine mammals in response to the appearance of new suitable habitats and to the modification of their prey distribution. In northeast Greenland, for example, the coastal waters between 72 and $80^{\circ}$ Lat. North were until recently covered year round by multiyear drift ice transported from the Polar Basin by the East Greenland Current. Historically, this coast only hosted a few, small breeding seabird colonies. ${ }^{100}$ Recent changes in sea ice regimes (both in extent and duration) are providing opportunities for this region to host larger seabird populations (e.g., kittiwakes Rissa tridactyla and common eiders Somateria mollissima) and for the establishment of new breeding species-like black-backed gulls Larus marinus and Larus fuscus. ${ }^{101-104}$ The kittiwake nicely illustrates the ongoing changes in range shifts for widespread species: its populations are increasing and its distribution range is expanding in the Arctic, while they are simultaneously declining in Europe at the southern border of its range. ${ }^{102,103,105}$ The first records of gray seals Halichoerus grypus in southern Greenland, harbor porpoise Phocoena phocoena in Svalbard and well-documented shifts in gray whale Eschrichtius robustus distribution suggest that range shifts are also occurring quite broadly among marine mammals that are resulting in traditionally more southerly species spending more time in the Arctic as well as regular Arctic migrants staying for longer periods. ${ }^{41}$

Another consequence of the reduction of sea ice is that many islands currently connected to the mainland by ice bridges for most of the year will become ice free for a longer period. This loss of connectivity will prevent access for predator species like the Arctic fox Vulpes lagopus to some bird colonies during the breeding period and will strongly benefit birds nesting on these islands, as already seen for common eiders in Canada. ${ }^{106}$ On a larger spatial and temporal scale, it is also likely that the small Arctic fox populations historically found on Jan Mayen and Bjørnøya (Norway) — two oceanic islands holding important seabird colonies in summer but no alternative food resources to sustain fox populations during the winter period-declined and eventually became extinct in recent decades due to the loss of sea ice connectivity, making regular immigration from large nearby populations - that is, northeast Greenland and Spitzbergen-difficult. ${ }^{107,108}$ Although extensive sea ice periods have promoted population exchanges among Arctic fox, reindeer, and other terrestrial mammal populations, they have actually limited population exchange within marine mammals and conversely, of course, periods with little sea ice have promoted population linkages and genetic exchange for marine mammals. ${ }^{109}$ Less sea ice in the future is almost certain to promote more extensive and regular population exchange among various marine mammal species, particularly among those cetaceans that have extensive migrations as a normal part of their annual cycles. ${ }^{110}$ 
Simultaneously, the warming of the oceans has also led to important changes in zooplankton and fish communities, and several studies predict these modifications will continue. ${ }^{111}$ The overall trend is a northward movement of species along with a replacement of Arctic species by more temperate ones with different energetic values-for example, the replacement of the cold adapted, lipid-rich copepods Calanus hyperboreus and C. glacialis by southern, low-lipid C. finmarchicus being a particularly well-studied example. ${ }^{81}$ These sorts of changes will indirectly impact breeding seabirds and marine mammals through bottom-up control processes. ${ }^{112}$ Because these Arctic marine top predators are often specialized, their fate will depend on their ability to modify their diet according to new prey conditions, a plasticity that has already been shown in several Arctic species but within given limits. ${ }^{113,114}$

For the long-distance migratory Arctic shorebirds, climate change effects on their staging and wintering areas may be just as-or even moreimportant than conditions in the Arctic. ${ }^{21}$ This is because most of them stop over and winter along marine coasts, on a small number of exceedingly important intertidal areas, where sea level rise or other climate-related changes may modify their current feeding grounds (e.g., in the West European Wadden Sea, Banc de Arguin in West Africa, the Yellew Sea in East Asia, and Copper River Delta in southern Alaska). ${ }^{115}$

For all these reasons, overall distribution ranges of most Arctic vertebrates are predicted to shift northward, and population sizes of many of them are likely to decline as a consequence of the reduction of their habitats and immigration of new competitors. However, in the Arctic, gains and losses will not be similar to other biomes, ${ }^{116}$ because only a few vertebrate taxa are likely to disappear while many "new" ones will colonize from the South. The paradox here is that species richness in the Arctic will undoubtedly increase in the future-more species colonizing than species disappearing-but Arctic biodiversity, that is, its contribution to the biological diversity on a worldwide scale as defined by its original sense, ${ }^{117,118}$ can only decline. Indeed, the many taxa colonizing from the South will often just expand or shift their ranges northward (see the kittiwake example described earlier), while the few Arctic ones, only present in this biome and that have no alternate region to colonize to the North, will see their populations decline and in some cases even go extinct.

\section{Cascading changes and feedbacks: from population dynamics to ecosystem functioning}

Arctic ecosystems are hypothesized to have little functional redundancy. Changes in the phenology, distribution, or behavior of species-as already described in previous sections-may therefore have disproportional impacts on the abundance and dynamics of species, and in turn on the structure and functioning of their communities and ecosystems. Therefore, the impacts of climate change cannot be inferred or predicted using either single-species approaches or simple empirical relationships between processes and driving variables. To understand these changes and predict their consequences, one must instead explore them in a multitrophic and multispecies perspective, particularly in the Arctic. ${ }^{119-121}$

Climate change has already been shown to affect life-history traits like survival and reproductive success of many Arctic vertebrates. ${ }^{122-124}$ Climatedriven impacts on dynamics are, however, often more difficult to understand because impacts also vary in direction and strength depending on how trophic interactions are disrupted. ${ }^{125}$ Small rodents in general and lemmings in particular provide good examples of such interspecific interactions across several trophic levels. Lemmings are central to the multitrophic interactions in the Arctic tundra and play a key role in shaping the structure and dynamics of these ecosystems. They impact reproduction and abundance of many terrestrial Arctic predators, ${ }^{126,127}$ which in turn creates feedbacks on lemming cyclic dynamics as well as on the dynamics of other vertebrate prey. ${ }^{128,129}$ In Greenland and in Scandinavia, lemming cycles have recently been fading out. ${ }^{15,16,130}$ This situation is not particularly surprising given the evidence from both paleo- and current records showing that rodent population dynamics are highly influenced by climate variables in the Arctic, in particular by snow characteristics. ${ }^{11,12,15,16,129,131,132}$ Not only does snow provide insulation from the harsh Arctic weather, but a thick snow cover also prevents most predator access to the subnivean rodents. ${ }^{133}$ For lemmings in particular, sufficient snow cover is important for winter breeding. ${ }^{11,12}$ The ongoing and future changes in temperature and snow conditions are therefore expected 
to have important implications for the population dynamics of lemmings, in terms of both increased length of the lemming cycle and reduced peak densities. ${ }^{16,129}$ Such changes in rodent dynamics will have immediate effects on the predator community, not only in terms of reduced abundance and productivity, ${ }^{16}$ but also in terms of more indirect effects on the predation pressure on alternative prey species, such as ground-nesting birds. ${ }^{134-138}$ Ultimately, this may even affect the geographical distribution of shorebirds and other species sensitive to predation. ${ }^{139}$ The fading out of the small mammal population cycles will have far-reaching, cascading effects, ultimately impacting the structure and functioning of the entire terrestrial Arctic ecosystem. ${ }^{130,140}$ As lemmings are key grazer and browsers of Arctic plants, loss of cyclic lemming outbreaks will also feedback on important structural components of the vegetation like tall shrubs. ${ }^{141}$ Consequently, negative effects of climate warming on lemmings may create a positive feedback on the ongoing greening of the Arctic owing to shrubs encroaching on tundra plant communities. ${ }^{142}$ Finally, shrub encroachment is predicted to provide a positive feedback on the climate system itself through more absorption of sunlight that is converted to heat. ${ }^{143}$

Changes in distribution ranges - see the previous section-can also impact the population dynamics of competing species and deeply modify the structure of communities. In Scandinavia, there is now extensive empirical evidence that the larger red fox Vulpes vulpes can expel its smaller congener, the arctic fox, from food resources in winter ${ }^{144}$ and from breeding territories ${ }^{145}$ and dens ${ }^{146}$ in summer. During the last century, the red fox has extended its range northwards into the tundra zone at the expense of the Arctic fox, which has retracted its southern distribution limits. ${ }^{147,148}$ Although it has been suggested that the range expansion of the red fox is related to climate warming and concomitant increased primary productivity of the tundra, ${ }^{147}$ the link to increased secondary productivity and hence food for carnivores has yet to be demonstrated. ${ }^{149}$ In this context, it is important to keep in mind that the Arctic is changing not only due to climate change, but also for other reasons owing to local anthropogenic activities-e.g., intensified land use, infrastructure, settlements-which may pave the way for highly adaptive generalist predators like the red fox and corvids. ${ }^{144}$
Bylot Island provides another interesting example of altered community function. Reproduction of snow geese is strongly affected by weather conditions prevailing in spring at this location. When the spring is early and warm, the probability of laying eggs increases, that is, the nest density is higher, laying is early, and individuals lay larger clutches, resulting in a higher reproductive effort at the population level. ${ }^{72,150,151}$ But climate also drives primary production. In wetlands used by geese, production has increased by $85 \%$ during the period of 1990-2009, most likely as a direct consequence of the warming temperatures. The cumulative number of thawing degree-days during the summer is an important determinant of plant biomass at the end of the summer. ${ }^{152}$ Although this suggests that snow geese should benefit from climate warming, other factors such as increasing mismatch between the timing of breeding and plant phenology (see section earlier) could mitigate these effects. Moreover, in recent decades, goose population increases have largely been driven by events occurring during winter-mostly food subsidy provided by feeding in agricultural lands - and this has had negative impacts with snow geese overgrazing their Arctic breeding habitat in several localities. ${ }^{153,154}$ Thus, climatic effects cannot be fully understood without considering all factors affecting the dynamics of a population.

The well-known influences of large, mammalian herbivores on primary production and plant community composition may play a role in ecosystem responses to climate change in areas with increasing or stable populations of large herbivores. Experimental evidence indicates, for example, that grazing by caribou and muskoxen in West Greenland suppresses the positive response of woody, deciduous shrubs to warming, maintaining the plant community in a graminoid-dominated state. ${ }^{155} \mathrm{Be}$ cause woody shrubs have a much greater carbon uptake potential than do graminoids, this suggests mammalian herbivores may have the potential in some parts of the Arctic to constrain carbon uptake by ecosystems in response to warming. Indeed, experimental warming resulted in a threefold increase in ecosystem carbon uptake in West Greenland, but only where caribou and muskoxen had been excluded; in sites where these herbivores grazed warmed plots, there was no net increase in carbon uptake in response to warming. ${ }^{156}$ 
As seen earlier, climate change will impact the dynamics of Arctic multitrophic systems whether they are bottom-up or top-down controlled. Other important clues to understanding these impacts are space and time. Even a significant impact of climate on breeding success can take several years to show effects in many species. For instance, it takes the young several years to reach sexual maturity and return to the breeding sites in many seabird or marine mammal species. ${ }^{157}$ In addition, one needs to account for regional climate change variation, particularly for animals that use areas experiencing different degrees of change during their annual cycles, in order to comprehensively assess changes in population dynamics. Arctic terns Sterna paradisaea winter in sub-Antarctic waters while little auks remain in Arctic waters, despite the fact that both breed in the High Arctic. These two species will of course be differently exposed and differently impacted by climate change. ${ }^{112,158}$ Even the lemming predator community described in the previous example is indirectly linked to pelagic intertropical climates, via two skua species that are highly specialized on lemming prey spending the summer in the Arctic but the rest of the year in the south. ${ }^{159,160}$ But despite the recent development of year-round tracking devices, our knowledge is still mostly restricted to the summer season for many Arctic migrants, while spatial distribution or foraging behavior are still poorly known during the nonbreeding season, which is of course an essential period in these animals' life cycles. ${ }^{53}$

\section{The cryptic parasites}

The overall health of an individual is the result of many interactions between its immune status, body condition, pathogens, exposure to pollutants, and other environmental conditions that influence these factors. ${ }^{161}$ Because climate is one of the main factors driving the diversity, distribution, and abundance of pathogens, understanding how climate changes might affect host-pathogen interactions is a major, though often overlooked, challenge. ${ }^{162}$ As the Arctic climate becomes warmer and wetter, profound changes are expected in host-parasite interactions; many pathogens are sensitive to temperature, rainfall, and humidity. The transmission rates of pathogens and their period of transmission will become longer in warmer conditions. ${ }^{163-165}$ This change could have profound consequences on Arctic vertebrates, because parasites are known to in- fluence individual fitness and in turn population dynamics. ${ }^{16-170}$

Several climate-driven changes in host-parasite interactions are already obvious in the Arctic, and several reviews have recently been devoted to the effects of climate change on parasite infections and the ecological and evolutionary consequences for Arctic vertebrates. ${ }^{162,171-173}$ Overall, these studies suggest that climate warming can increase pathogen development and survival rates, disease transmission, and host susceptibility through at least three main mechanisms.

First, global warming could change the abundance as well as spatial and temporal distribution of existing parasites. Indeed, the life cycles of numerous parasites are more efficient in warmer conditions, and global warming is hence expected to increase the success of infective stages. One of the best examples of this phenomenon is the infection of muskoxen by the nematode Umingmakstrongylus pallikuukensis. ${ }^{163}$ Empirical field and laboratory data have demonstrated that the life cycle of this parasite has become shorter due to temperature increases, resulting in an increased parasite burdens for their host. ${ }^{163}$ Increases in pathogen infections linked to warmer temperature have also been documented for other parasites in muskox, ${ }^{174}$ reindeer, ${ }^{175}$ marine mammals, ${ }^{176}$ and seabirds. ${ }^{170}$ Second, global warming might also induce northward range shifts of parasites due to the relaxation of the environmental constraints that affect their survival and developmental rates. For example, in Canada, the northern limit of the moose winter tick Dermacentor albipictus has already significantly expanded. ${ }^{173}$ Finally, temperature increase will facilitate the arrival and establishment of new pathogen species previously unknown in the North and for which Arctic hosts have no previous exposure and hence no immunity. ${ }^{177} \mathrm{~A}$ number of studies have shown that new parasites are currently emerging in northern ungulates due to climate change, modified movements of animals, and population density. ${ }^{178}$ Direct impacts of new parasites on naive host population could lead to epidemic disease outbreaks (e.g., Elaphostrongylus rangiferi within caribou in Newfoundland). ${ }^{179}$

There is no doubt that climate change is already altering the dynamics of host-parasite interactions in the Arctic. Such changes will have profound impacts on population dynamics of hosts and 
for the ecology and evolution of Arctic vertebrates, although the consequences of these changes have not yet been properly evaluated.

\section{Evolutionary responses}

Most studies to date that have attempted to forecast the impact of climate change on species and communities have used phenomenological models based on species niche, largely ignoring the species' adaptive potential and biotic interactions. ${ }^{180}$ Many examples have already been given throughout this review to emphasize the importance of biotic interactions, but evolutionary responses are likely also important to consider because evolution is a permanent and sometimes rapid process that can mitigate the effects of climate change. ${ }^{181,182}$

\section{Change in phenology: adjust where you live}

Phenology is a key aspect of the adaptation of Arctic vertebrates. The short growing season in the Arctic represents a challenge for most animals, and life-history strategies of successful Arctic vertebrates have evolved to enable individuals to fulfill their life cycles under time constraints and high environmental unpredictability. ${ }^{6}{ }^{183}$ In such a highly seasonal environment, offspring production is timed to coincide with the annual peak of resource availabilitysee section "Advanced phenology." The mechanisms that allow organisms to cope with climate-induced phenological changes are likely to be of two basic kinds.

Phenotypic plasticity-changes within individuals - allows organisms to rapidly cope with shortterm changes in the environment without a change in genotypes. Some individuals in a population can accommodate large amounts of environmental variation while other individuals can tolerate only a narrow range of environmental variation. ${ }^{184}$ Across the circumpolar Arctic, species are regionally exposed to varying sets of environmental conditions in different parts of their range and thus may demonstrate considerable plasticity. ${ }^{66}$ But plasticity will also depend on species-specific sensitivity to climate change that may vary according to population size, geographic range, habitat specificity, diet diversity, migration, site fidelity, sensitivity to changes in sea ice, sensitivity to changes in the trophic web, and maximum population growth potential. This series of factors allowed Laidre et al. ${ }^{43}$ to quantify the sensitivity of seven Arctic and four subarctic marine mammal species. According to their sensitivity index, the hooded seal Cystophora cristata, the polar bear, and the narwhal appear to be the three most sensitive Arctic marine mammal species, primarily due to reliance on sea ice and specialized feeding. The least sensitive species were the ringed seal and bearded seal, primarily due to large circumpolar distributions, currently large population sizes, and flexible habitat requirements. Although, the very specific breeding requirements of ringed seals (for snow availability on sea ice that must last for a period of months) probably warrants their inclusion in the most sensitive category. ${ }^{41}$

There are limits to plastic responses, and they are unlikely to provide long-term solutions for the challenges currently facing populations of Arctic vertebrates, especially for specialized species that are experiencing continued directional environmental change. ${ }^{185,186}$ Microevolutionary changes-that is, changes in gene frequencies between generationsallow populations to cope with longer-term environmental changes through permanent modifications of phenotypes and will reflect selection on phenotypic traits. ${ }^{187}$ As climate warming continues, shifting optima for phenological traits-for example, the timing of development, reproduction, migration, or fall dormancy-will at some point exceed the limits of individual plasticity and selection for genetic change in populations will occur. Indeed, when faced with long-term directional changes in environmental conditions, evolutionary adaptation becomes essential for the long-term persistence of populations.

Evolutionary response to selection will depend on the presence of heritable variation-that is, standing genetic variation within populations and additional variation generated by mutation and immigration. ${ }^{188-190}$ However, there is growing evidence that populations of Arctic species have relatively low genetic diversity, a pattern observed for such diverse species as polar bears, ${ }^{22}$ muskoxen, ${ }^{191} \mathrm{col}$ lared lemmings Dicrostonyx groenlandicus, ${ }^{132}$ and the wolf Canis lupus. ${ }^{192}$ Most studies suggest that the Last Glacial Maximum (25.0-18.0 cal. kyr BP), which was strongly associated with a cold and dry climate, had strong effects on the genetic variation of Arctic vertebrates. High Arctic shorebird species have probably been through similar genetic bottlenecks since the last interglacial, in contrast with 
low-Arctic and sub-Arctic species that show extensive polymorphism. ${ }^{21}$ This likely indicates that High Arctic shorebirds have been repeatedly exposed to "Arctic squeeze"-that is, their southern limit of distribution being pushed northwards, while they could not move farther North due to the Arctic Ocean barrier (see also section "Poleward shifts").

Although one may therefore expect a constant decrease of genetic diversity for current Arctic populations and low evolutionary potential, it should be mentioned that most studies done to date have used neutral markers (e.g., mitochondrial DNA) to evaluate the level of genetic variation within and between populations. Hence, they may have little bearing on real measures of genetic variation in morphology and life-history traits, which are directly exposed to selection. Few Arctic vertebrates have been studied using a quantitative genetic approach that addresses the potential for rapid adaptation to climatic change. Using such a quantitative genetic approach, Réale et al. ${ }^{193}$ showed that northern boreal red squirrels Tamiasciurus hudsonicus were able to respond to increased temperatures both plastically and genetically within a decade. Pedigree analysis showed that about $13 \%$ of the 18-day advance in mean parturition date was genetic and that $62 \%$ of the change in breeding dates was a result of phenotypic plasticity. This study emphasizes the need for extensive, long-term ecological and quantitative genetic data for estimating the relative roles of evolution and plasticity on response to climate change. Given that species with short generation times tend to have higher rates of molecular evolution, ${ }^{194}$ we can expect that long-generation-time species such as bowheads or the monodont whales should have less evolutionary potential to respond to new selective pressures than shorter generation-time species such as shorebirds or rodents. ${ }^{183}$

\section{Range shifts: tracking suitable habitats}

Global warming over the past 40 years has shifted the ecological niche of many species spatially-that is, towards the poles or higher altitudes (see section "Poleward shifts"). An ability to track shifting habitat is critically influenced by individual dispersal, which is key to the dynamics of genetic diversity in time and space and has profound effects on the ecological structure and dynamics of populations. ${ }^{180,195}$ In the meantime, however, global warming might cause an overall contraction and fragmen- tation of the distribution range of Arctic vertebrates, eventually below the critical level of metapopulation persistence. ${ }^{196,197}$ Future decreases of sea ice extent will lead to a loss of connectivity between Arctic regions, preventing or impeding dispersal of pagophilic species in summer. Even for some terrestrial mammals like the Arctic fox, sea ice is necessary for long-distance dispersal. ${ }^{198,199}$ Genetic structure of fox populations is therefore likely to change dramatically in the future, both at the circumpolar scale and within populations, as a consequence of the ongoing sea ice declines (see also section "Poleward shifts"). ${ }^{108,200,201}$

To improve our knowledge of the evolutionary consequences of climate change, we can also learn from the past. The Quaternary period (the past 2.6 Myr) was marked by glacial-interglacial phases and can be used as a model system to infer how Arctic species have responded to past climatic variation. In order to track their preferred habitats, species should increase their distribution ranges during periods of suitable climate and conversely contract them when climate conditions become unsuitable. The lesson we have learned from the past is that for temperate species, warming periods are often indicative of range expansions, while for Arctic species (e.g., muskox), populations are seen to increase during global climatic cooling and decline during the warmer and climatically unstable interglacial period. ${ }^{191}$

Finally, a different approach to study past demographic changes is to use ancient DNA, which allows the study of dynamic genetic variation over time. Thanks to well-preserved samples buried in permafrost, this approach has been used in several Arctic species-e.g., muskoxen, ${ }^{191}$ collared lemming, ${ }^{132}$ and Arctic fox. ${ }^{202}$ The results show that for the Arctic fox, populations in middle Europe became extinct at the end of the Pleistocene-ca. $18 \mathrm{Kyr}$ ago - and did not track its habitat when it shifted to the north. These results suggest that some populations, despite high specific dispersal capabilities, ${ }^{198,199}$ might be unable to track their habitats. ${ }^{202}$ For collared lemming, results also showed that previous climate events have strongly influenced genetic diversity and population size. ${ }^{132}$ Due to its already reduced genetic diversity, a further decrease would strongly impede the evolutionary potential of this species. Local extinctions of collared lemmings would in turn have severe effects on the 
entire terrestrial ecosystem, and perhaps even beyond it into the marine environment (see section "Cascading changes"). ${ }^{16,126,152}$

\section{Missing pieces}

Due to low species richness, relatively simple functioning, and high exposure to climate changes, Arctic ecosystems are already being strongly impacted by climate-driven changes and are among the best candidates to study ecological impacts of this phenomenon. ${ }^{6,123,140}$ Arctic ecologists often advertise their studies for their inferential potential-that is, for the overall knowledge that can be gained from their study to understand and possibly mitigate the impact of climate change in other ecosystems that are not yet, or not so strongly, impacted. Even if we agree with these statements in general, we also call for great caution when discussing the results of such studies on larger taxonomic or geographical scales. For the time being, most studies claiming to show impacts of climate change-in the Arctic and elsewhere-are species oriented and only present correlative evidence. They are therefore speculative because they only consider a small fraction of the interacting species and have a limited predictive value since they often do not explicitly study the factors driving these population dynamics. Metaanalyses, experiments, and modeling studies can partly address these problems, but they also have weaknesses-for example, low predictive power at the species level, ${ }^{90}$ narrow scope for the second because only a few parameters can be tested simultaneously, and too many nontestable assumptions. Below, we address a few of these missing pieces.

\section{Cryptic indirect interactions}

As seen in the previous sections, interspecific interactions strongly influence how climate change affects organisms - for example, competition, parasitism, and predation can impact behavior, individual fitness, geographic range, and ultimately the structure and dynamics of the community-but are too often overlooked. ${ }^{120}$ Predators, for example, are both impacting and in turn impacted by their preysee section "Cascading changes." But interspecific interactions also often produce indirect and unpredictable impacts. ${ }^{203,204}$ In Scandinavia, for instance, the impact of increasing red fox populations on the regionally endangered Arctic fox is thought to be mediated by their shared microtine prey-that is, "exploitative competition." 205 In the High Arctic, the breeding success of some waders and wildfowl is sometimes assumed to mirror changes in lemming densities mediated by shared predators - that is, "apparent competition." $136,137,139,206$

Precipitation can also lead to unforeseen changes in interspecific interactions. Lecomte et al. ${ }^{207}$ recently showed that water availability-and rainfall-affects the interaction between snow geese and the Arctic fox. Egg predation is reduced in years of high rainfall because incubating females walk shorter distances from their nest to drink and feed and therefore have a better chance to defend their nests from predators. Because climate change should affect precipitation regimes in the Arctic, ${ }^{3,6}$ this may impact nesting success of geese by changing water availability for incubating females. However, the direction of the effect is difficult to predict because although total precipitation should increase, it may be concentrated in fewer, more intense rainfall events.

Even though they are strong enough to shape entire vertebrate communities, such indirect interactions are often difficult to discern without longterm, large-scale, and multispecies time series. Such data sets are rare for Arctic systems. An additional challenge is to untangle climate-driven changes from other anthropogenic impacts. In Canada, for example, the predation of large gulls Larus argentatus and Larus marinus on kittiwake is sometimes linked to the availability of capelin Mallotus villosus, and when capelin are scarce, kittiwakes suffer higher predation from large gulls. But capelin availability is driven both by climate and fishing pressure. $^{208}$

\section{The winter gap}

Until recently, and with the exception of a few species, our ecological knowledge of most Arctic vertebrates has been extremely limited for the winter period. Yet this time, season is very important to the understanding of the dynamics of species. Exchanges of resources across ecosystem boundaries are known to impact food webs, especially in lowproductive Arctic systems. ${ }^{152}$ Because most Arctic vertebrates are to some extent migratory and make use of different ecosystems during their annual cycles, they contribute to such exchanges. In recent years, satellite tracking has allowed major progress in our knowledge of nonbreeding distribution and 
migration flyways of many large Arctic vertebrates, and geolocators are currently filling the gaps for small, site fidel birds species. Thanks to these advances, we recently learned that several of the terrestrial predators that reproduce in the Arctic tundra in summer make extensive use of the sea ice ecosystem during the winter period. ${ }^{199,209,210}$ This unexpected behavior - at least for the snowy owl and the gyrfalcon-undoubtedly impacts the fitness of these individuals and their subsequent impact on terrestrial prey in the tundra ecosystem during the breeding season. Consequently, the current changes in sea ice regimes may also increase the vulnerability of these predators to climate warming. ${ }^{152}$ Further technological innovations will hopefully allow us to gain more knowledge regarding the winter ecology of many others species in the near future.

\section{"Subsidies"}

Anthropogenic food resources and animal carcasses have often been an overlooked resource in the pastexcept for typical scavenging species-when assessing energy flows and population dynamics of Arctic vertebrate communities. Yet these alternate food resources are currently increasing in the Arctic, both as a consequence of climate change-for example, herbivores suffer higher mortality due to icing events ${ }^{140}$ —and increasing human activitiesfor example, reindeer management ${ }^{149}$ and fishing waste. ${ }^{211}$ Increasing numbers of ungulate carcasses, for example, are assumed to benefit red foxes in Scandinavia, which can in turn negatively impact the regionally endangered Arctic fox. ${ }^{149,212}$ Similarly, it is assumed that spatio-temporal differences in muskox mortality impacts the population dynamics of Arctic foxes and stoats Mustela erminea in northeast Greenland, which could in turn explain regional differences in the amplitude and cycle length of lemming fluctuations. ${ }^{16}$ Because the availability of such alternate food is likely to increase in the future or at least change in abundance and distribution, it is important to consider them in future studies aiming to assess population dynamics of Arctic vertebrates.

\section{Tipping points}

Ecosystems do not always respond in smooth, linear, and reversible ways to pressures. As seen in previous sections, many Arctic species will first be able to buffer the effects of climate change to some extentfor example, thanks to their behavioral plasticity.
But such abilities are limited, and "points of no return" might be reached when conditions change sufficiently. Complex systems in particular are often characterized by nonlinear responses to changes and can have thresholds that once passed lead to abrupt and irreversible changes. ${ }^{213}$ Such thresholds, or "tipping points," are highly unpredictable in biological systems, because they can be the result of a number of changes in the population dynamics of several interacting species. Any taxon that disappears from an assemblage or even just declines due to climate change will alter ecosystem functioning. This can lead to sudden, steep, and irreversible changes in Arctic ecosystems where vertebrates have low functional redundancy (see also section "Cascading changes").

When tipping points result from a single dominant driving force, their consequences can be easier to foresee. For example, thermal windows have given limits (see section "Ecophysiological constraints"). The dynamics of a species can remain relatively stable as long as the climate fluctuates within these limits, but might suddenly and rapidly decline once these limits are crossed. In addition, species can only adjust their phenologies to a changing environment within given limits-for example, long-distance migrants need a minimum period of time to build up fat reserves on their wintering and staging grounds and then to travel all the way to their breeding grounds. Hence, their arrival in the Arctic cannot be brought forward indefinitely. Similarly, plasticity of diets has limits, which once crossed-that is, when the more profitable food items become too "expensive" to get-will rapidly impact fitness. Finally, some biotic tipping points can just mechanistically mirror abiotic tipping point. The reduction of sea ice, for instance, is believed to have geophysical tipping points according to some climate models, ${ }^{214}$ which would induce correlated tipping points for pagophilic species.

\section{Where are the Arctic vertebrates heading?}

Due to the large variance in climate models, inherent complexity of natural systems, and the difficulties of implementing large-scale, long-term, and multi-trophic studies in the Arctic, predictions of climate-induced ecological impacts are difficult and remain highly speculative. ${ }^{119,215}$ Even though predictions might be easier in the Arctic than elsewhere, the Arctic is nonetheless a complex system where 
climate conditions, physical environments, or food web structure can be markedly different. Different species or even individuals within a species can react differently to similar environmental modifications according to their location and their current life-history strategy. Predictions made for a spatially restricted area might not be applicable to other regions and could lead to wrong interpretations, predictions, and management plans. ${ }^{216}$

The best example of an Arctic vertebrate for which we have enough knowledge to reach this aim with relatively high confidence is the iconic polar bear. Several studies have tried to predict what may happen to polar bears and their habitat in the coming decades. Because the biology of polar bears in different subpopulations around the Arctic varies considerably $^{23}$ and vital demographic parameters vary in unpredictable ways with environmental change, the predicted outcomes must be considered cautiously. But given the future predictions regarding sea ice in most climate models, it is clear that the optimal habitat of polar bears will be severely reduced in the coming decades. This habitat where polar bears hunt and spend most of their time is mainly "not too old sea ice over not too deep waters, not too far from land." ${ }^{216}$ In addition, multiyear sea ice is an important denning habitat north of Alaska, while in other areas sufficient snow fall in autumn is necessary to form snow drifts where maternity dens will not thaw or collapse. Sea ice around denning areas must be in place in time for the autumn to permit access and also remain long enough to provide hunting possibilities for ringed seals in the spring. A model based on the expected changes of polar bear habitat, in combination with demographic and environmental data, has predicted a strong decline in the number of polar bears, with total extirpation in areas currently holding two thirds of the world population by $2050 .{ }^{217}$ However, Amstrup et al. ${ }^{218}$ point out that slowing greenhouse gas emissions could reduce loss of polar bear habitat and stop their decline in large parts of the Arctic. The intimate connection between polar bear distribution and sea ice allows us to predict where polar bears will likely survive in the future. The decline in survival, reproduction, and population size of the western Hudson Bay population has given us some information on the maximum ice-free periods that polar bears can tolerate, though the precise length of this period will depend on the productivity in each area and access to alternative prey. High Arctic Canada and North Greenland are most likely the only regions where polar bear populations are likely to survive in the future if summer sea ice continues to decline as predicted by most sea ice models.

Although further work is needed before we can draw similarly precise predictive scenario for most other Arctic vertebrates, the current knowledge summarized in this review nonetheless indicates that climate change driven impacts on Arctic vertebrates follow some general trends.

- Because the annual cycle of most Arctic vertebrates is tightly linked with the cryosphere (i.e., snow cover for terrestrial species and sea ice for marine ones), they will have to adjust their phenologies to these new conditions on the short term, especially in order to avoid trophic mismatches.

- As vegetation belts and associated species move northward, Arctic vertebrates will eventually have to follow these range shifts in order to track their optimal living conditions. With a few exceptions, this will mechanistically lead to the reduction of their distribution ranges, particularly among High Arctic species.

- For the most pronounced High Arctic species, range shift may not be possible and selection for adaptive genotypes may be too slow, if possible at all. These species will face the highest risk of extinction during the coming decades.

- The speed of these range shifts will for the most part be species specific. Due to these specific differences, the structure of the vertebrate communities will necessarily change in the future. It is expected that climate warming will have stronger impacts on specialist feeders, which are less prone to respond to a rapid change in prey availability, distribution, and quality.

- Because many Arctic vertebrates have long generation times and sometimes highly variable dynamics, a climate-induced reduction in individual fitness may take significant periods of time to become perceptible in the population dynamics of Arctic vertebrates.

- New interspecific interactions will appear in Arctic communities-for example, between current competitors, predator-prey, or parasite-host arrangements of species- 
with highly unpredictable cascading changes, including feedbacks, in the dynamics of populations and ultimately in the functioning of these modified ecosystems. Due to these complex relations, even small changes in climate can potentially lead to dramatic ecological changes-for example, top-down regulated populations could well become bottom-up regulated in some cases or vice versa.

- Many of these ecological changes that are likely to occur in the coming decades are nonlinear, both in slope and intensity, and some can reach tipping points. Small differences in environmental conditions can lead to very different impacts between otherwise similar populations or regions.

- Our current knowledge of the impacts of climate change on Arctic vertebrates is hampered by major knowledge gaps in the ecology of the species-for example, the winter period or on the nonbreeding grounds for migratory species - and does not generally consider other anthropogenic impacts-for example, see section "Subsidies."

How climate change will impact peoples through changes in the occurrence of Arctic vertebrates is a question that we did not implicitly address in this review. However, from most of our examples, one can ascertain that Arctic peoples depending on traditional lifestyles will also be strongly impacted. Impacts on reindeer distribution, especially in North America, will deeply impact the economy and the culture of some Arctic and subArctic peoples. Changes in fish, marine mammal, and seabird availability, central species in the economy and culture of many Arctic peoples, will also impact their societies and will force them to adjust their relationship with their environment and perhaps adopt new environmental and management policies. ${ }^{219,220}$ Most of the examples discussed in our review actually have cascading impacts on peoples.

Despite the uncertainties associated to the many empirical and theoretical works available in the literature forecasting the fate of Arctic vertebrates, their future is at risk, especially the Arctic endemic species, which are highly adapted to survive in harsh Arctic environments that have been restrictive to other species. What can be taken for granted at least is that they will undergo dramatic changes in the coming years and decades. But any precise, specific prediction of their future state, even at the circumpolar scale, remains highly speculative given our currently limited knowledge and the complexity of the processes involved. There is even some doubt about the widespread claim that Arctic species are more sensitive to climate change impacts than other species; some recent studies have suggested that they might actually be more resilient to climate change, based on the fact that they have already undergone more dramatic changes in the recent past than species from other biomes. ${ }^{221}$ Given all the doubts and major knowledge gaps, a conservative approach to mitigation policies is warranted at this time. $^{218}$

\section{Acknowledgments}

We are grateful to the Conseil Régional de Bourgogne and the French Polar Institute (IPEV) for its support to the project "1036-Interactions" (to OG, JM and LB) and to the latter for its support to the project "388-Adaclim" (to JF and DG). Climate change research in Norway has been funded largely by the Norwegian Research Council's IPY and NORKLIMA research programs. Some of the researches reviewed herein have also been supported by the Norwegian Polar Institute.

\section{Conflicts of interest}

The authors declare no conflicts of interest.

\section{References}

1. Walther, G.-R. et al. 2002. Ecological responses to recent climate change. Nature, 416: 389-395.

2. Parmesan, C. 2006. Ecological and evolutionary responses to recent climate change. Ann. Rev. Ecol. Evol. Syst. 37: 637669.

3. IPCC. 2007. Climate Change 2007. Synthesis report. IPCC, Valencia.

4. Vibe, C. 1967. Arctic animals in relation to climatic fluctuations. Meddelelser om Grønland 170: 1-227.

5. Barber, D.G. \& J. Iacozza. 2004. Historical analysis of sea ice conditions in M'Clintock Channel and the Gulf of Boothia, Nunavut: implications for ringed seal and polar bear habitat. Arctic 57: 1-14.

6. ACIA. 2005. Arctic Climate Impact Assessment. Cambridge University Press, Cambridge.

7. Overland, J.E. \& M.Y. Wang. 2010. Large-scale atmospheric circulation changes are associated with the recent loss of Arctic sea ice. Tellus Series a-Dyn. Meteorol. Oceanogr. 62: $1-9$. 
8. Polyak, L. et al. 2010. History of sea ice in the Arctic. Quat. Sci. Rev. 29: 1757-1778.

9. Parmesan, C. \& G. Yohe. 2003. A globally coherent fingerprint of climate change impacts across natural systems. Nature 421: 37-42.

10. Root, T.L. et al. 2003. Fingerprints of global warming on wild animals and plants. Nature 421: 57-60.

11. Ims, R.A., N.G. Yoccoz \& S.T. Killengreen. 2011. Determinants of lemming outbreaks. Proc. Nat. Acad. Sci. USA 108: 1970-1974.

12. Duchesne, D., G. Gauthier \& D. Berteaux, 2011. Habitat selection, reproduction and predation of wintering lemmings in the Arctic. Oecologia 167: 967-980.

13. Sittler, B. 1995. Response of stoat (Mustela erminea) to a fluctuating lemming (Dicrostonyx groenlandicus) population in North East Greenland: preliminary results from a long term study. Ann. Zool. Fennici 32: 79-92.

14. Reid, D., F. Bilodeau, et al. Lemming winter habitat choice: a snow-fencing experiment. Oecologia, in press. doi:10.1007/s00442-011-2167-x

15. Kausrud, K.L. et al. 2008. Linking climate change to lemming cycles. Nature 456: 93-97.

16. Gilg, O., B. Sittler \& I. Hanski. 2009. Climate change and cyclic predator-prey population dynamics in the highArctic. Global Change Biol. 15: 2634-2652.

17. Forchhammer, M. et al. 2005. Local-scale and short-term herbivore-plant spatial dynamics reflect influences of largescale climate. Ecology 86: 2644-2651.

18. Tyler, N.J.C., M.C. Forchhammer \& N.A. Oritsland. 2008. Nonlinear effects of climate and density in the dynamics of a fluctuating population of reindeer. Ecology 89: 16751686.

19. Meltofte, H. 1996. Are African wintering waders really forced south by competition from northerly wintering conspecifics? Benefits and constraints of northern versus southern wintering and breeding in waders. Ardea 84: 31-44.

20. Lyon, B. \& R. Montgomerie. 1995. Snow Bunting and McKay's Bunting (Plectrophenax nivalis, and Plectrophenax hyperboreus). In Birds of North America No. 198-199. A. Poole \& F. Gill, eds. The Academy of Natural Sciences, Philadelphia, and the American Ornithologists' Union, Washington, D.C.

21. Meltofte, H. et al. 2007. Effects of climate variation on the breeding ecology of Arctic shorebirds. Meddelelser om Grønland-Bioscience 59: 1-48.

22. Lindqvist, C. et al. 2010. Complete mitochondrial genome of a Pleistocene jawbone unveils the origin of polar bear. Proc. Nat. Acad. Sci. USA 107: 5053-5057.

23. Amstrup, S.C. 2003. Polar Bear (Ursus maritimus). In Wild Mammals of North America: Biology, Management and Conservation. G.A. Feldhamer, B.C. Thopmson \& J.A. Chapman, Eds.: 587-610. Johns Hopkins University Press, Baltimore, MD.

24. Freitas, C. et al. 2012. Importance of fast ice and glacier fronts for female polar bears and their cubs during spring in Svalbard, Norway. Mar. Ecol. Prog. Ser., in press. doi:10.3354/meps09516

25. Mauritzen, M., A.E. Derocher \& O. Wiig. 2001. Space-use strategies of female polar bears in a dynamic sea ice habi- tat. Can. J. Zool.-Revue Canadienne De Zoologie 79: 17041713.

26. Wiig, O., J. Aars \& E.W. Born. 2008. Effects of climate change on polar bears. Sci. Prog. 91: 151-173.

27. Stirling, I. \& A.E. Derocher. 1993. Possible impacts of climatic warming on polar bears. Arctic 46: 240-245.

28. Derocher, A.E., N.J. Lunn \& I. Stirling. 2004. Polar bears in a warming climate. Integr. Comp. Biol. 44: 163-176.

29. Regehr, E.V. et al. 2007. Effects of earlier sea ice breakup on survival and population size of polar bears in western Hudson bay. J. Wildlife Manag. 71: 2673-2683.

30. Regehr, E.V. et al. 2010. Survival and breeding of polar bears in the southern Beaufort Sea in relation to sea ice. J. Animal Ecol. 79: 117-127.

31. Fischbach, A., S. Amstrup \& D. Douglas. 2007. Landward and eastward shift of Alaskan polar bear denning associated with recent sea ice changes. Polar Biol. 30: 1395 1405.

32. Amstrup, S.C. et al. 2006. Recent observations of intraspecific predation and cannibalism among polar bears in the southern Beaufort Sea. Polar Biol. V29: 997-1002.

33. Monnett, C. \& J. Gleason. 2006. Observations of mortality associated with extended open-water swimming by polar bears in the Alaskan Beaufort Sea. Polar Biol. 29: 681-687.

34. Durner, G.M. et al. 2011. Consequences of long-distance swimming and travel over deep-water pack ice for a female polar bear during a year of extreme sea ice retreat. Polar Biol. 34: 975-984.

35. Jenssen, B.M. 2006. Endocrine-disrupting chemicals and climate change: a worst-case combination for arctic marine mammals and seabirds? Environ. Health Perspect. 114: 7680.

36. MacGarvin, M. \& M.P. Simmonds. 1996. Whales and climate change. In The Conservation of Whales and Dolphins, Science Practice. M.P. Simmonds \& J.D. Hutchinson, Eds.: 321-332. John Wiley and Sons. Chichester, UK.

37. Tynan, C.T. \& D.P. DeMaster. 1997. Observations and predictions of Arctic climatic change: potential effects on marine mammals. Arctic 50: 308-322.

38. Kelly, B.P. 2001. Climate change and ice breeding pinnipeds. In "Fingerprints" of Climate Change, G.-R. Walther, C.A. Burga \& P.J. Edwards, Eds.: 43-55. Kluwer Academic/Plenum Publications, New York.

39. Johnston, D.W. et al. 2005. Variation in sea ice cover on the east coast of Canada from 1969 to 2002: climate variability and implications for harp and hooded seals. Clim. Res. 29: 209-222.

40. Simmonds, M.P. \& S.J. Isaac. 2007. The impacts of climate change on marine mammals: early signs of significant problems. Oryx 41: 19-26.

41. Kovacs, K. et al. 2011. Impacts of changing sea-ice conditions on Arctic marine mammals. Mar. Biodivers. 41: 181-194.

42. Kovacs, K.M. \& C. Lydersen. 2008. Climate change impacts on seals and whales in the North Atlantic Arctic and adjacent shelf seas. Sci. Prog. 91: 117-150.

43. Laidre, K. et al. 2008. Quantifying the sensitivity of Arctic marine mammals to climate-induced habitat change. Ecol. Appl. 18(Suppl.): S97-S125. 
44. Moore, S.E. \& H.P. Huntington. 2008. Arctic marine mammals and climate change: impacts and resilience. Ecol. Appl. 18: S157-S165.

45. Ragen, T.J., H.P. Huntington \& G.K. Hovelsrud. 2008. Conservation of Arctic marine mammals faced with climate change. Ecol. Appl. 18: S166-S174.

46. Kern, S., L. Kaleschke \& G. Spreen. 2010. Climatology of the Nordic (Irminger, Greenland, Barents, Kara and White/Pechora) Seas ice cover based on $85 \mathrm{GHz}$ satellite microwave radiometry: 1992-2008. Tellus Series a-Dyn. Meteorol. Oceanogr. 62: 411-434.

47. White, J.W.C. et al. 2010. Past rates of climate change in the Arctic. Quat. Sci. Rev. 29: 1716-1727.

48. Johannessen, O.M. \& M.W. Miles. 2010. Critical vulnerabilities of marine and sea ice-based ecosystems in the high Arctic. Region. Environ. Change 11: S239-S248.

49. Heide-Jorgensen, M.P. \& K. Laidre. 2004. Declining extent of open-water refugia for top predators in Baffin Bay and adjacent waters. Ambio 33: 487-494.

50. Stirling, I. 1997. The importance of polynyas, ice edges, and leads to marine mammals and birds. J. Mar. Syst. 10: 9-21.

51. Harington, C.R. 2008. The evolution of Arctic marine mammals. Ecol. Appl. 18: S23-S40.

52. Williams, T.M.W.T.M., S.R. Noren \& M. Glenn. 2011. Extreme physiological adaptations as predictors of climatechange sensitivity in the narwhal, Monodon monoceros. Mar. Mammal Sci. 27: 334-349.

53. Fort, J., W.P. Porter \& D. Gremillet. 2009. Thermodynamic modelling predicts energetic bottleneck for seabirds wintering in the northwest Atlantic. J. Exp. Biol. 212: 2483-2490.

54. Gaston, A.J. \& I.L. Jones, Eds. 1998. Bird Families of the World: the Auks. Oxford University Press, New York.

55. Hoegh-Guldberg, O. \& J.F. Bruno. 2010. The impact of climate change on the World's marine ecosystems. Science 328: $1523-1528$.

56. Pörtner, H.O. \& A.P. Farrell. 2008. Physiology and climate change. Science 322: 690-692.

57. Farrell, A.P. et al. 2008. Pacific Salmon in hot water: applying aerobic scope models and biotelemetry to predict the success of spawning migrations. Physiol. Biochem. Zool. 81: 697-708.

58. Perry, A.L. et al. 2005. Climate change and distribution shifts in marine fishes. Science 308: 1912-1915.

59. Helaouet, P. \& G. Beaugrand. 2007. Macroecology of Calanus finmarchicus and C-helgolandicus in the North Atlantic Ocean and adjacent seas. Mar. Ecol.-Prog. Ser. 345: 147-165.

60. Humphries, M.M., J. Umbanhowar \& K.S. McCann. 2004. Bioenergetic prediction of climate change impacts on northern mammals. Integr. Comp. Biol. 44: 152-162.

61. Boonstra, R. 2004. Coping with changing northern environments: the role of the stress axis in birds and mammals. Integr. Comp. Biol. 44: 95-108.

62. Bustnes, J.O., K.O. Kristiansen \& M. Helberg. 2007. Immune status, carotenoid coloration, and wing feather growth in relation to organochlorine pollutants in great black-backed gulls. Arch. Environ. Contam. Toxicol. 53: 96102.

63. Bustnes, J.O., G.W. Gabrielsen \& J. Verreault. 2010. Climate variability and temporal trends of persistent organic pollutants in the Arctic: a study of Glaucous Gulls. Environ. Sci. Technol. 44: 3155-3161.

64. Grémillet, D. \& A. Charmantier. 2010. Shifts in phenotypic plasticity constrain the value of seabirds as ecological indicators of marine ecosystems. Ecol. Appl. 20: 1498-1503.

65. Parmesan, C. 2007. Influences of species, latitudes and methodologies on estimates of phenological response to global warming. Global Change Biol. 13: 1860-1872.

66. Høye, T.T. et al. 2007. Rapid advancement of spring in the High Arctic. Curr. Biol. 17: R449-R451.

67. Carey, C. 2009. The impacts of climate change on the annual cycles of birds. Philos. Trans. R. Soc. B-Biol. Sci. 364: 3321-3330.

68. Durant, J.M. et al. 2007. Climate and the match or mismatch between predator requirements and resource availability. Clim. Res. 33: 271-283.

69. Post, E. \& M.C. Forchhammer. 2008. Climate change reduces reproductive success of an Arctic herbivore through trophic mismatch. Philos. Trans. R. Soc. B-Biol. Sci. 363: 2369-2375.

70. Miller-Rushing, A.J. et al. 2010. The effects of phenological mismatches on demography. Philos. Trans. R. Soc. B-Biol. Sci. 365: 3177-3186.

71. Lepage, D., G. Gauthier \& A. Reed. 1998. Seasonal variation in growth of greater snow goose goslings: the role of food supply. Oecologia 114: 226-235.

72. Dickey, M.-E., G. Gauthier \& M.-C. Cadieux. 2008. Climatic effects on the breeding phenology and reproductive success of an arctic-nesting goose species. Global Change Biol. 14: 1973-1985.

73. Post, E. et al. 2008. Warming, plant phenology and the spatial dimension of trophic mismatch for large herbivores. Proc. R. Soc. B-Biol. Sci. 275: 2005-2013.

74. Lu, W.Q. et al. 2010. A Circadian Clock is not required in an Arctic Mammal. Curr. Biol. 20: 533-537.

75. Meltofte, H. et al. 2007. Differences in food abundance cause inter-annual variation in the breeding phenology of High Arctic waders. Polar Biol. V30: 601-606.

76. Tulp, I. \& H. Schekkerman. 2008. Has prey availability for arctic birds advanced with climate change? Hindcasting the abundance of tundra arthropods using weather and seasonal variation. Arctic 61: 48-60.

77. Vatka, E., M. Orell \& S. Rytkönen. 2011. Warming climate advances breeding and improves synchrony of food demand and food availability in a boreal passerine. Global Change Biol. 17: 3002-3009.

78. Falk, K. \& S. Møller. 1997. Breeding ecology of the fulmar Fulmarus glacialis and the Kittiwake Rissa tridactyla in higharctic northeastern Greenland, 1993. Ibis. 139: 270-281.

79. Mallory, M.L. \& M.R. Forbes. 2007. Does sea ice constrain the breeding schedules of high Arctic Northern Fulmars? Condor 109: 894-906.

80. Laidre, K.L. et al. 2008. Latitudinal gradients in sea ice and primary production determine Arctic seabird colony size in Greenland. Proc. R. Soc. B: Biol. Sci. 275: 2695-2702.

81. Reygondeau, G. \& G. Beaugrand. 2011. Future climatedriven shifts in distribution of Calanus finmarchicus. Global Change Biol. 17: 756-766. 
82. Gilg, O. et al. 2010. Post-breeding movements of the northeast Atlantic ivory gull Pagophila eburnea populations. J. Avian Biol. 41: 532-542.

83. Gaston, A.J., H.G. Gilchrist \& J.M. Hipfner. 2005. Climate change, ice conditions and reproduction in an Arctic nesting marine bird: Brunnich's guillemot (Uria lomvia L.). J. Anim. Ecol. 74: 832-841.

84. Rockwell, R.F., L.J. Gormezano \& D.N. Koons. 2011. Trophic matches and mismatches: can polar bears reduce the abundance of nesting snow geese in western Hudson Bay? Oikos 120: 696-709.

85. Drent, R.H. \& J. Prop. 2008. Barnacle goose Branta leucopsis survey on Nordenskiöldkysten, west Spitsbergen 19752007: breeding in relation to carrying capacity and predator impact. Circumpolar Stud. 4: 59-83.

86. Moe, B. et al. 2009. Climate change and phenological responses of two seabird species breeding in the high-Arctic. Mar. Ecol.-Prog. Ser. 393: 235-246.

87. Taylor, S.G. 2008. Climate warming causes phenological shift in Pink Salmon, Oncorhynchus gorbuscha, behavior at Auke Creek, Alaska. Global Change Biol. 14: 229-235.

88. Malcolm, J.R. et al. 2006. Global warming and extinctions of endemic species from biodiversity hotspots. Conserv. Biol. 20: $538-548$.

89. Dingemanse, N.J. et al. 2010. Behavioural reaction norms: animal personality meets individual plasticity. Trends Ecol. Evol. 25: 81-89.

90. Chen, I.-C. et al. 2011. Rapid range shifts of species associated with high levels of climate warming. Science 333: 1024-1026.

91. Huntley, B. et al. 2006. Potential impacts of climatic change upon geographical distributions of birds. Ibis 148: 8-28.

92. Beaumont, L.J. et al. 2007. Where will species go? Incorporating new advances in climate modelling into projections of species distributions. Global Change Biol. 13: 1368 1385.

93. Levinsky, I. et al. 2007. Potential impacts of climate change on the distributions and diversity patterns of European mammals. Biodivers. Conserv. 16: 3803-3816.

94. Wisz, M.S. et al. 2008. Where might the western Svalbard tundra be vulnerable to pink-footed goose (Anser brachyrhynchus) population expansion? Clues from species distribution models. Diversity Distrib. 14: 26-37.

95. Speed, J.D.M. et al. 2009. Predicting habitat utilization and extent of ecosystem disturbance by an increasing Herbivore population. Ecosystems 12: 349-359.

96. Jensen, R.A. et al. 2008. Prediction of the distribution of Arctic-nesting pink-footed geese under a warmer climate scenario. Global Change Biol. 14: 1-10.

97. Gilg, O. et al. 2009. Status of the endangered Ivory Gull, Pagophila eburnea, in Greenland. Polar Biol. 32: 1275-1286.

98. Schwartz, M.W. et al. 2006. Predicting extinctions as a result of climate change. Ecology 87: 1611-1615.

99. Thomas, C.D. et al. 2004. Extinction risk from climate change. Nature 427: 145-148.

100. Boertmann, D. 1994. A annotated checklist to the birds of Greenland. Meddelelser om Grønland-Bioscience 38: 1-63.

101. Boertmann, D. \& R.D. Nielsen. 2010. Geese, seabirds and mammals in North and Northeast Greenland. Aerial sur- veys in summer 2009. NERI. Technical Report no. 773. NERI. Copenhagen.

102. Labansen, A.L. et al. 2010. Status of the black-legged kittiwake (Rissa tridactyla) breeding population in Greenland, 2008. Polar Res. 29: 391-403.

103. Gilg, O. et al. 2005. Ecopolaris - Tara 5 expedition to NE Greenland 2004. GREA. Francheville.

104. Boertmann, D. 2008. The lesser black-backed gull, Larus fuscus, in Greenland. Arctic 61: 129-133.

105. Sandvik, H., T.I.M. Coulson \& B.-E. Saether. 2008. A latitudinal gradient in climate effects on seabird demography: results from interspecific analyses. Global Change Biol. 14: $1-11$.

106. Chaulk, K.G., G.J. Robertson \& W.A. Montevecchi. 2007. Landscape features and sea ice influence nesting common eider abundance and dispersion. Can. J. Zool. 85: 301-309.

107. Rouvinen-Watt, K. 2004. Biological premises for management of an Arctic fox (Alopex lagopus) population - The demise and future of the hare-footed fox on Jan Mayen. In Jan Mayen Island in Scientific Focus, S. Skreslet, Ed.: 207218. Springer. Dordrecht.

108. Geffen, E.L.I. et al. 2007. Sea ice occurrence predicts genetic isolation in the Arctic fox. Mol. Ecol. 16: 4241-4255.

109. Corry-Crowe, G. 2008. Climate change and the molecular ecology of Arctic marine mammals. Ecol. Appl. 18: S56-S76.

110. Heide-Jørgensen, M.P. et al. 2011. The Northwest Passage opens for bowhead whales. Biol. Lett. in press. doi:10.1098/rsbl.2011.0731

111. Beaugrand, G., M. Edwards \& L. Legendre. 2010. Marine biodiversity, ecosystem functioning, and carbon cycles. Proc. Nat. Acad. Sci. USA 107: 10120-10124.

112. Karnovsky, N. et al. 2010. Foraging distributions of little auks Alle alle across the Greenland Sea: implications of present and future Arctic climate change. Mar. Ecol.-Prog. Ser. 415: 283-293.

113. Karnovsky, N.J. et al. 2003. Foraging behavior of little auks in a heterogeneous environment. Mar. Ecol.-Prog. Ser. 253: 289-303.

114. Barrett, R.T. \& Y.V. Krasnov. 1996. Recent responses to changes in stocks of prey species by seabirds breeding in the southern Barents Sea. ICES J. Mar. Sci. 53: 713-722.

115. van de Kam, J. et al., eds. 2004. Shorebirds. An Illustrated Behavioural Ecology. KNNV Publishers. Utrecht.

116. Wardle, D.A. et al. 2011. Terrestrial ecosystem responses to species gains and losses. Science, 332: 1273-1277.

117. Kaschner, K. et al. 2011. Current and future patterns of global marine mammal biodiversity. PLoS One 6: E19653. doi:10.1126/science. 1183010

118. UNEP, ed. 1995. Global Biodiversity Assessment. Cambridge University Press. Cambridge.

119. Wookey, P.A. et al. 2009. Ecosystem feedbacks and cascade processes: understanding their role in the responses of Arctic and alpine ecosystems to environmental change. Global Change Biol. 15: 1153-1172.

120. Gilman, S.E. et al. 2010. A framework for community interactions under climate change. Trends Ecol. Evol. 25: 325331.

121. Van der Putten, W.H. et al. 2004. Trophic interactions in a changing world. Basic Appl. Ecol. 5: 487-494. 
122. Sandvik, H. et al. 2005. The effect of climate on adult survival in five species of North Atlantic seabirds. J. Anim. Ecol. 74: 817-831.

123. Post, E. et al. 2009. Ecological dynamics across the Arctic associated with recent climate change. Science, 325: 13551358.

124. Callaghan, T.V. et al. 2005. Arctic tundra and polar desert ecosystems. In Arctic Climate Impact Assessment, ACIA: 243-352. Cambridge University Press. Cambridge.

125. Van der Putten, W.H., M. Macel \& M.E. Visser. 2010. Predicting species distribution and abundance responses to climate change: why it is essential to include biotic interactions across trophic levels. Philos. Trans. R. Soc. B-Biol. Sci. 365: 2025-2034.

126. Gilg, O. et al. 2006. Functional and numerical responses of four lemming predators in high arctic Greenland. Oikos 113: 196-213.

127. Gauthier, G. et al. 2004. Trophic interactions in a High Arctic snow goose colony. Integr. Comp. Biol. 44: 119-129.

128. Gilg, O., I. Hanski \& B. Sittler. 2003. Cyclic dynamics in a simple vertebrate predator-prey community. Science 302: 866-868.

129. Schmidt, N.M. et al. 2008. Vertebrate predator-prey interactions in a seasonal environment. Adv. Ecol. Res. 40: 345-370.

130. Ims, R.A., J.-A. Henden \& S.T. Killengreen. 2008. Collapsing population cycles. Trends Ecol. Evol. 23: 79-86.

131. Berg, T.B. et al. 2008. High-arctic plant-herbivore interactions under climate influence. Adv. Ecol. Res. 40: 275-298.

132. Prost, S. et al. 2010. Influence of climate warming on Arctic mammals? New insights from ancient DNA studies of the collared Lemming Dicrostonyx torquatus. PLoS One 5: e10447.

133. Hansson, L. \& H. Henttonen. 1985. Gradients in density vriations of small rodents: the importance of latitude and snow cover. Oecologia 67: 394-402.

134. McKinnon, L. et al. 2010. Lower predation risk for migratory birds at high latitudes. Science 327: 326-327. doi:10.1126/science. 1183010

135. Summers, R.W., L.G. Underhill \& E.E. Syroechkovski. 1998. The breeding productivity of dark-bellied brent geese and curlew sandpipers in relation to changes in the numbers of arctic foxes and lemmings on the Taimyr Peninsula, Siberia. Ecography 21: 573-580.

136. Bêty, J. et al. 2001. Are goose nesting success and lemming cycles linked? Interplay between nest density and predators. Oikos 93: 388-400.

137. Bêty, J. et al. 2002. Shared predation and indirect trophic interactions: lemming cycles and arctic-nesting geese. J. Anim. Ecol. 71: 88-98.

138. Blomqvist, S. et al. 2002. Indirect effects of lemming cycles on sandpiper dynamics: 50 years of counts from southern Sweden. Oecologia 133: 146-158.

139. Gilg, O. \& N.G. Yoccoz. 2010. Explaining bird migration. Science 327: 276-277.

140. Ims, R.A. \& E. Fuglei. 2005. Trophic interaction cycles in Tundra ecosystems and the impact of climate change. BioScience 55: 311-322.

141. Ravolainen, V.T. et al. 2011. Rapid, landscape scale responses in riparian tundra vegetation to exclusion of small and large mammalian herbivores. Basic Appl. Ecol. 12: 643653.

142. Sturm, M., C. Racine \& K. Tape. 2001. Climate change - Increasing shrub abundance in the Arctic. Nature 411: 546-547.

143. Chapin, F.S. et al. 2005. Role of land-surface changes in Arctic summer warming. Science 310: 657-660.

144. Killengreen, S.T. et al. How ecological neighbourhoods influence the structure of the scavenger guild in low arctic tundra. Divers. Distrib. in press. doi:10.1111/j.14724642.2011.00861.x

145. Tannerfeldt, M., B. Elmhagen \& A. Angerbjörn. 2002. Exclusion by interference competition? The relationship between red and arctic foxes. Oecologia 132: 213-220.

146. Rodnikova, A. et al. 2011. Red fox takeover of arctic fox breeding den: an observation from Yamal Peninsula, Russia. Polar Biology 34: 1609-1614.

147. Hersteinsson, P. \& D.W. Macdonald. 1992. Interspecific competition and the geographical distribution of red and arctic foxes Vulpes vulpes and Alopex lagopus. Oikos 64: 505-515.

148. Killengreen, S.T. et al. 2007. Structural characteristics of a low Arctic tundra ecosystem and the retreat of the Arctic fox. Biol. Conserv. 135: 459-472.

149. Killengreen, S.T. et al. 2011. The importance of marine vs. human-induced subsidies in the maintenance of an expanding mesocarnivore in the arctic tundra. J. Animal Ecol. 80: 1049-1060.

150. Morrissette, M. et al. 2010. Climate, trophic interactions, density dependence and carry-over effects on the population productivity of a migratory Arctic herbivorous bird. Oikos 119: 1181-1191.

151. Reed, E.T., G. Gauthier \& J.-F. Giroux. 2004. Effects of spring conditions on breeding propensity of greater snow goose females. Animal Biodivers. Conserv. 27: 3546.

152. Gauthier, G. et al. 2011. The tundra food web of Bylot Island in a changing climate and the role of exchanges between ecosystems. Ecoscience 18: 223-235.

153. Jefferies, R.L., R.F. Rockwell \& K.F. Abraham. 2004. Agricultural food subsidies, migratory connectivity and large-scale disturbance in arctic coastal systems: a case study. Integr. Comp. Biol. 44: 130-139.

154. Gauthier, G. et al. 2005. Interactions between land use, habitat use and population increase in greater snow geese: what are the consequences for natural wetlands? Global Change Biol. 11: 856-868.

155. Post, E. \& C. Pedersen. 2008. Opposing plant community responses to warming with and without herbivores. Proc. Nat. Acad. Sci. USA 105: 12353-12358.

156. Cahoon, S.M.P. et al. 2012. Large herbivores limit $\mathrm{CO}_{2}$ uptake and suppress carbon cycle responses to warming in West Greenland. Global Change Biol. 18: 469-479. doi:10.1111/j.1365-2486.2011.02528.x

157. Thompson, P.M. \& J.C. Ollason. 2001. Lagged effects of ocean climate change on fulmar population dynamics. $\mathrm{Na}$ ture 413: 417-420.

158. Egevang, C. et al. 2010. Tracking of Arctic terns Sterna paradisaea reveals longest animal migration. Proc. Nat. Acad. Sci. USA 107: 2078-2081. 
159. Furness, R.W. 1987. The Skuas. Calton. Poyser.

160. Sittler, B., A. Aebischer \& O. Gilg. 2011. Post-breeding migration of four Long-tailed Skuas (Stercorarius longicaudus) from North and East Greenland to West Africa. J. Ornithol. 152: 375-381.

161. Burek, K.A., F.M.D. Gulland \& T.M. Hara. 2008. Effects of climate change on Arctic marine mammal health. Ecol. Appl. 18: S126-S134.

162. Kutz, S.J., A.P. Dobson \& E.P. Hoberg. 2009. Where are the parasites? Science 326: 1187-1188.

163. Kutz, S.J. et al. 2005. Global warming is changing the dynamics of Arctic host-parasite systems. Proc. R. Soc. B-Biol. Sci. 272: 2571-2576.

164. Harvell, C.D. et al. 2002. Climate warming and disease risks for terrestrial and marine biota. Science 296: 2158-2162.

165. Polley, L. \& R.C.A. Thompson. 2009. Parasite zoonoses and climate change: molecular tools for tracking shifting boundaries. Trends Parasitol. 25: 285-291.

166. Hudson, P.J., A.P. Dobson \& D. Newborn. 1998. Prevention of population cycles by parasite removal. Science 282: 22562258.

167. Hudson, P.J., A.P. Dobson \& D. Newborn. 1992. Do parasites make prey vulnerable to predation - Red grouse and parasites. J. Animal Ecol. 61: 681-692.

168. Albon, S.D. et al. 2002. The role of parasites in the dynamics of a reindeer population. Proc. R. Soc. Lond. Ser. B-Biol. Sci. 269: 1625-1632.

169. Jenkins, E.J., E.P. Hoberg \& L. Polley. 2005. Development and pathogenesis of Parelaphostrongylus odocoilei (Nematoda : Protostrongylidae) in experimentally infected thinhorn sheep (Ovis dalli). J. Wildlife Dis. 41: 669-682.

170. Gaston, A.J., J.M. Hipfner \& D. Campbell. 2002. Heat and mosquitoes cause breeding failures and adult mortality in an Arctic-nesting seabird. Ibis 144: 185-191.

171. Davidson, R. et al. 2011. Arctic parasitology: why should we care? Trends Parasitol. 27: 238-244.

172. Hueffer, K., T.M. O’Hara \& E.H. Follmann. 2011. Adaptation of mammalian host-pathogen interactions in a changing arctic environment. Acta Veterinaria Scandinavica 53: 17. doi:10.1186/1751-0147-53-17

173. Kutz, S.J. et al. 2009. The Arctic as a model for anticipating, preventing, and mitigating climate change impacts on hostparasite interactions. Vet. Parasitol. 163: 217-228.

174. Ytrehus, B. et al. 2008. Fatal pneumonia epizootic in musk ox (Ovibos moschatus) in a period of extraordinary weather conditions. Ecohealth 5: 213-223.

175. Laaksonen, S. et al. 2010. Climate change promotes the emergence of serious disease outbreaks of Filarioid Nematodes. Ecohealth 7: 7-13.

176. Jensen, S.K. et al. 2010. The prevalence of Toxoplasma gondii in polar bears and their marine mammal prey: evidence for a marine transmission pathway? Polar Biol. 33: 599-606.

177. Hoberg, E.P. et al. 2008. Integrated approaches and empirical models for investigation of parasitic diseases in northern wildlife. Emerg. Infect. Dis. 14: 10-17.

178. Kutz, S.J. et al. 2004. "Emerging" parasitic infections in arctic ungulates. Integr. Comp. Biol. 44: 109-118.

179. Ball, M.C., M.W. Lankester \& S.P. Mahoney. 2001. Factors affecting the distribution and transmission of
Elaphostrongylus rangiferi (Protostrongylidae) in caribou (Rangifer tarandus caribou) of Newfoundland, Canada. Can. J. Zool. 79: 1265-1277.

180. Lavergne, S. et al. 2010. Biodiversity and climate change: integrating evolutionary and ecological responses of species and communities. Annual Review of Ecology, Evolution, and Systematics 41:321-350. doi:10.1146/annurev-ecolsys102209-144628

181. Skelly, D.K. et al. 2007. Evolutionary responses to climate change. Conserv. Biol. 21: 1353-1355.

182. Hoffmann, A.A. \& C.M. Sgro. 2011. Climate change and evolutionary adaptation. Nature 470: 479-485.

183. Berteaux, D. et al. 2004. Keeping pace with fast climate change: can Arctic life count on evolution? Integr. Comp. Biol. 44: 140-151.

184. Bradshaw, W.E. \& C.M. Holzapfel. 2008. Genetic response to rapid climate change: it's seasonal timing that matters. Mol. Ecol. 17: 157-166.

185. Pigliucci, M. 2001. Phenotypic Plasticity; Beyond Nature and Nurture. Syntheses in Ecology and Evolution. John Hopkins University Press, Baltimore, MD.

186. Gienapp, P. et al. 2008. Climate change and evolution: disentangling environmental and genetic responses. Mol. Ecol. 17: $167-178$.

187. Bradshaw, W.E. \& C.M. Holzapfel. 2006. Climate change - Evolutionary response to rapid climate change. Science 312: $1477-1478$

188. Barton, N. \& L. Partridge. 2000. Limits to natural selection. BioEssays 22: 1075-1084.

189. Bürger, R. \& M. Lynch. 1995. Evolution and extinction in a changing environment: a quantitative-genetic analysis. Evolution 49: 151-163.

190. Falconer, D.S. \& T.F.C. Mackay. 1996. Introduction to Quantitative Genetics. 4th ed. Pearson Education. Essex, UK.

191. Campos, P.F. et al. 2010. Ancient DNA analyses exclude humans as the driving force behind late Pleistocene musk ox (Ovibos moschatus) population dynamics. Proc. Nat. Acad. Sci. USA 107: 5675-5680.

192. Leonard, J.A. et al. 2007. Megafaunal extinctions and the disappearance of a specialized wolf ecomorph. Curr. Biol. 17: 1146-1150.

193. Reale, D. et al. 2003. Genetic and plastic responses of a northern mammal to climate change. Proc. R. Soc. Lond. Ser. B-Biol. Sci. 270: 591-596.

194. Bromham, L., A. Rambaut \& P. Harvey. 1996. Determinants of rate variation in mammalian DNA sequence evolution. J. Mol. Evol. 43: 610-621.

195. Hanski, I. 1999. Metapopulation Ecology. Oxford University Press. Oxford.

196. Opdam, P. \& D. Wascher. 2004. Climate change meets habitat fragmentation: linking landscape and biogeographical scale levels in research and conservation. Biol. Conserv. 117: 285-297.

197. Hanski, I. \& O. Ovaskainen. 2000. The metapopulation capacity of a fragmented landscape. Nature 404: 755758.

198. Noren, K. et al. 2011. Pulses of movement across the sea ice: population connectivity and temporal genetic structure in the arctic fox. Oecologia 166: 973-984. 
199. Tarroux, A., D. Berteaux \& J. Bêty. 2010. Northern nomads: ability for extensive movements in adult arctic foxes. Polar Biol. 33: 1021-1026.

200. Noren, K. et al. 2009. Farmed arctic foxes on the Fennoscandian mountain tundra: implications for conservation. Animal Conserv. 12: 434-444.

201. Noren, K., A. Angerbjorn \& P. Hersteinsson. 2009. Population structure in an isolated Arctic fox, Vulpes lagopus, population: the impact of geographical barriers. Biol. J. Linnean Soc. 97: 18-26.

202. Dalen, L. et al. 2007. Ancient DNA reveals lack of postglacial habitat tracking in the arctic fox. Proc. Nat. Acad. Sci. USA 104: 6726-6729.

203. Ruscoe, W.A. et al. 2011. Unexpected consequences of control: competitive vs. predator release in a four-species assemblage of invasive mammals. Ecol. Lett. 14: 10351042.

204. Roemer, G.W., C.J. Donlan \& F. Courchamp. 2002. Golden eagels, feral pigs, and insular carnivores: how exotic species turn native predators into prey. Proc. Nat. Acad. Sci. USA 99: 791-796.

205. Henden, J.-A. et al. 2010. Strength of asymmetric competition between predators in food webs ruled by fluctuating prey: the case of foxes in tundra. Oikos 119: 27-34.

206. Sittler, B., O. Gilg \& T.B. Berg. 2000. Low abundance of King eider nests during low lemming years in Northeast Greenland. Arctic 53: 53-60.

207. Lecomte, N., G. Gauthier \& J.F. Giroux. 2009. A link between water availability and nesting success mediated by predator-prey interactions in the Arctic. Ecology 90: 465475.

208. Massaro, M. et al. 2000. Delayed capelin (Mallotus villosus) availability influences predatory behaviour of large gulls on black-legged kittiwakes (Rissa tridactyla), causing a reduction in kittiwak breeding success. Can. J. Zool. 78: 1588-1596.

209. Burnham, K.K. \& I.A.N. Newton. 2011. Seasonal movements of Gyrfalcons Falco rusticolus include extensive periods at sea. Ibis 153: $468-484$.
210. Therrien, J.-F., G. Gauthier \& J. Bêty. 2011. An avian terrestrial predator of the Arctic relies on the marine ecosystem during winter. J. Avian Biol. 42: 363-369.

211. Votier, S.C. et al. 2004. Changes in fisheries discard rates and seabird communities. Nature 427: 727-730.

212. Selås, V. \& J.O. Vik. 2006. Possible impact of snow depth and ungulate carcasses on red fox (Vulpes vulpes) populations in Norway, 1897-1976. J. Zool. 269: 299308.

213. Duarte, C. 2011. Not so smooth: thresholds and abrupt changes in ecosystems under pressure. In The Arctic in the Earth System Perspective: The Role of Tipping Points. Book of Abstracts. 13. University of Tromso. Tromso.

214. Winton, M. 2006. Does the sea ice have a tipping point? Geophys. Res. Lett. 33: 1-5.

215. Mustin, K., W.J. Sutherland \& J.A. Gill. 2007. The complexity of predicting climate-induced ecological impacts. Clim. Res. 35: 165-175.

216. Durner, G.M. et al. 2009. Predicting 21st-century polar bear habitat distribution from global climate models. Ecol. Monogr. 79: 25-58.

217. Amstrup, S.C., B.G. Marcot \& D.C. Dougles. 2008. A Bayesian network modeling approach to forecasting the 21st century worldwide status of polar bears, in Arctic Sea Ice Decline: observations, projections, mechanisms, and implications. Geophys. Monogr. Ser. 180: 213-268.

218. Amstrup, S.C. et al. 2010. Greenhouse gas mitigation can reduce sea-ice loss and increase polar bear persistence. $\mathrm{Na}$ ture 468: 955-958.

219. Huntington, H.P. \& S.E. Moore. 2008. Assessing the impacts of climate change on Arctic marine mammals. Ecol. Appl. 18: $\mathrm{S} 1-\mathrm{S} 2$.

220. Metcalf, V. \& M. Robards. 2008. Sustaining a healthy human-walrus relationship in a dynamic environment: challenges for comanagement. Ecol. Appl. 18: S148S156.

221. Beaumont, L.J. et al. 2011. Impacts of climate change on the world's most exceptional ecoregions. Proc. Nat. Acad. Sci. USA 108: 2306-2311. 